\title{
Status of hormones and painkillers in wastewater effluents across several European states - considerations for the EU watch list concerning estradiols and diclofenac
}

\author{
P. Schröder ${ }^{1}$ - B. Helmreich ${ }^{2}$ • B. Škrbić ${ }^{3}$ - M. Carballa ${ }^{4}$ - M. Papa ${ }^{5}$ - C. Pastore $^{6}$. \\ Z. Emre ${ }^{7}$ - A. Oehmen ${ }^{8}$ - A. Langenhoff ${ }^{9} \cdot$ M. Molinos $^{10}$ - J. Dvarioniene ${ }^{11} \cdot$ C. Huber ${ }^{1}$. \\ K. P. Tsagarakis ${ }^{12}$ - E. Martinez-Lopez ${ }^{13}$. S. Meric Pagano ${ }^{14}$. C. Vogelsang ${ }^{15}$. \\ G. Mascolo ${ }^{6}$
}

Received: 14 June 2015 / Accepted: 28 February 2016/Published online: 29 March 2016

(C) The Author(s) 2016. This article is published with open access at Springerlink.com

\begin{abstract}
Present technologies for wastewater treatment do not sufficiently address the increasing pollution situation of receiving water bodies, especially with the growing use of personal care products and pharmaceuticals (PPCP) in the private household and health sector. The relevance of addressing this problem of organic pollutants was taken into account by the Directive 2013/39/EU that introduced (i) the quality evaluation of aquatic compartments, (ii) the polluter pays principle, (iii) the need for innovative and affordable wastewater treatment technologies, and (iv) the identification of pollution causes including a list of principal compounds to
\end{abstract}

Responsible editor: Roland Kallenborn

Electronic supplementary material The online version of this article (doi:10.1007/s11356-016-6503-x) contains supplementary material, which is available to authorized users.

P. Schröder

peter.schroeder@helmholtz-muenchen.de

1 Research Unit Microbe-Plant Interactions (EGEN), German Research Center for Health and Environment GmbH, Helmholtz Zentrum Muenchen, Ingolstädter Landstr. 1, 85764 Neuherberg, Germany

2 Chair of Urban Water Systems Engineering, Technische Universität München, Munich, Germany

3 Faculty of Technology, University of Novi Sad, Novi Sad, Serbia

4 Department of Chemical Engineering, School of Engineering, University of Santiago de Compostela, Santiago de Compostela, Spain

5 Department of Civil Environmental Architectural Engineering \& Mathematics, University of Brescia, Brescia, Italy

6 CNR - Istituto di Ricerca Sulle Acque, Bari, Italy be monitored. In addition, a watch list of 10 other substances was recently defined by Decision 2015/495 on March 20, 2015. This list contains, among several recalcitrant chemicals, the painkiller diclofenac and the hormones $17 \beta$-estradiol and $17 \alpha$-ethinylestradiol. Although some modern approaches for their removal exist, such as advanced oxidation processes (AOPs), retrofitting most wastewater treatment plants with AOPs will not be acceptable as consistent investment at reasonable operational cost. Additionally, by-product and transformation product formation has to be considered. The same is true for membrane-based technologies (nanofiltration,
7 Turkish Atomic Energy Authority, Ankara, Turkey

8 Departamento de Química, Faculdade de Ciências e Tecnologia (FCT), Universidade Nova de Lisboa (UNL), Caparica, Portugal

9 Sub-department of Environmental Technology, Wageningen University of Agrotechnology \& Food Sciences, Wageningen, The Netherlands

10 University of Valencia, Valencia, Spain

11 Kaunas University of Technology, Kaunas, Lithuania

12 Business and Environmental Economics Technology Lab (BETECO), Department of Environmental Engineering, Democritus University of Thrace, Xanthi, Greece

13 University of Murcia, Murcia, Spain

14 Namık Kemal Üniversitesi, Tekirdağ, Turkey

15 Norwegian Institute for Water Research (NIVA), Oslo, Norway 
reversed osmosis) despite of the incredible progress that has been made during recent years, because these systems lead to higher operation costs (mainly due to higher energy consumption) so that the majority of communities will not easily accept them. Advanced technologies in wastewater treatment like membrane bioreactors (MBR) that integrate biological degradation of organic matter with membrane filtration have proven a more complete elimination of emerging pollutants in a rather cost- and labor-intensive technology. Still, most of the presently applied methods are incapable of removing critical compounds completely. In this opinion paper, the state of the art of European WWTPs is reflected, and capacities of single methods are described. Furthermore, the need for analytical standards, risk assessment, and economic planning is stressed. The survey results in the conclusion that combinations of different conventional and advanced technologies including biological and plant-based strategies seem to be most promising to solve the burning problem of polluting our environment with hazardous emerging xenobiotics.

Keywords Diclofenac $\cdot$ Ethinylestradiol $\cdot$ Emerging pollutants $\cdot$ Effluent quality $\cdot$ EU watch list $\cdot$ Pollutant removal $\cdot$ Advanced technologies

\section{Introduction and demand}

Across Europe, most people do not know where their drinking water comes from, and they are not aware of how big the efforts are to allow the performance of the most normal daily action, namely to open the tap and to consume clean, clear, and pure water. Still, it is the extremely high quality of our drinking water that guarantees the healthy life we lead. In fact, to provide unpolluted water as a resource for drinking water supply, food production but also other aspects of daily life will remain one of the major challenges for Europe in the near future. Novel emergent organic compounds (pharmaceuticals, industrial chemicals, personal care products, and others) pose a threat to our water reserves (Heberer 2002a, b; KasprzykHordern et al. 2008). These anthropogenic substances, often addressed as micropollutants that may adversely affect drinking water quality, are most typically polar to semipolar organic compounds detected at concentrations in the picogram per liter to microgram per liter range (Benner et al. 2013). Contamination of drinking water resources (surface water and groundwater) with these micropollutants raises important questions related to human health, ecology, and economic impacts (Benner et al. 2013). Among sources that are considered responsible for the occurrence of micropollutants in surface and groundwater, effluents of municipal wastewater treatment plants (WWTPs) are frequently pinpointed as the most important (Ternes 1998; Zuccato et al. 2006; KasprzykHordern et al. 2008). Whereas well-assessed treatment strategies exist for classical issues in WWTPs such as removal of biodegradable organic substances, nutrients (phosphorus and nitrogen), detergents, and even microorganisms, polar and semipolar micropollutants are not or only incompletely removed by these technologies. Hence, with the growing number of micropollutants being identified in surface water and groundwater, novel remediation and management strategies are needed to provide cost-effective and sustainable treatment solutions across Europe.

Since the majority of all significant water bodies, lakes, and streams are shared between several European countries, the European Union (EU) has to find a common strategy for remediation of micropollutants and to set limits for effluents from WWTPs. Furthermore, it will be necessary to expand the scope of water protection to all waters, surface waters and groundwater, to achieve satisfactory status for all waters by a set deadline, and to delegate water management to regional authorities based on river catchments. This is in part proposed by the European Water Framework Directive (see below: international conventions and agreements), which has already been implemented in most EU countries. The relevance of addressing the problem of organic pollutants was also taken into account by the Directive 2013/39/EU that introduced (i) the quality evaluation of aquatic compartments, (ii) the polluter pays principle, (iii) the need for innovative and affordable wastewater treatment technologies, and (iv) the identification of pollution causes including a list of principal compounds to be monitored.

Among thousands of micropollutants, not everything that can be measured is worth measuring, and not everything worth measuring is measurable. With regard to pharmaceutically active compounds, those to be monitored in natural waters should be related to prescription and nonprescription practices in each country (compare Fig. 1). It is very important to develop a ranking system to prioritize pharmaceutically active compounds considering the following four criteria: (a) occurrence (prevalence, frequency of detection), (b) highest percentages of excretion, (c) removal in treatment plants, and (d) ecological effects (bioaccumulation, ecotoxicity).

From the large number of micropollutants that fit this scheme, diclofenac (2-(2-(2,6-dichlorophenylamino)phenyl)acetic acid, DCF) and the estrogenic hormones $17 \beta$-estradiol $(1,3,5(10)$ estratrien-3,17 $\beta$-diol; E2) and $17 \alpha$-ethinylestradiol (19-nor$17 \alpha$-pregna-1,3,5(10)-trien-20-in-3,17-diol; EE2) have recently been included in the updated watch list of 10 other substances defined by Decision 2015/495 on March 20, 2015.

Diclofenac is a widely used nonsteroidal anti-inflammatory drug used as a painkiller prescribed as pills or ointments and among the most frequently detected pharmaceuticals in WWTP effluents, in microgram per liter concentrations (Verlicchi et al. 2012). E2 is a primary female sex hormone and key regulator of the estrous and menstrual female reproductive cycles, whereas EE2 is a synthetic, bioactive estrogen 
Fig. 1 Graphical representation of DCF and EE2 consumption levels across the EU

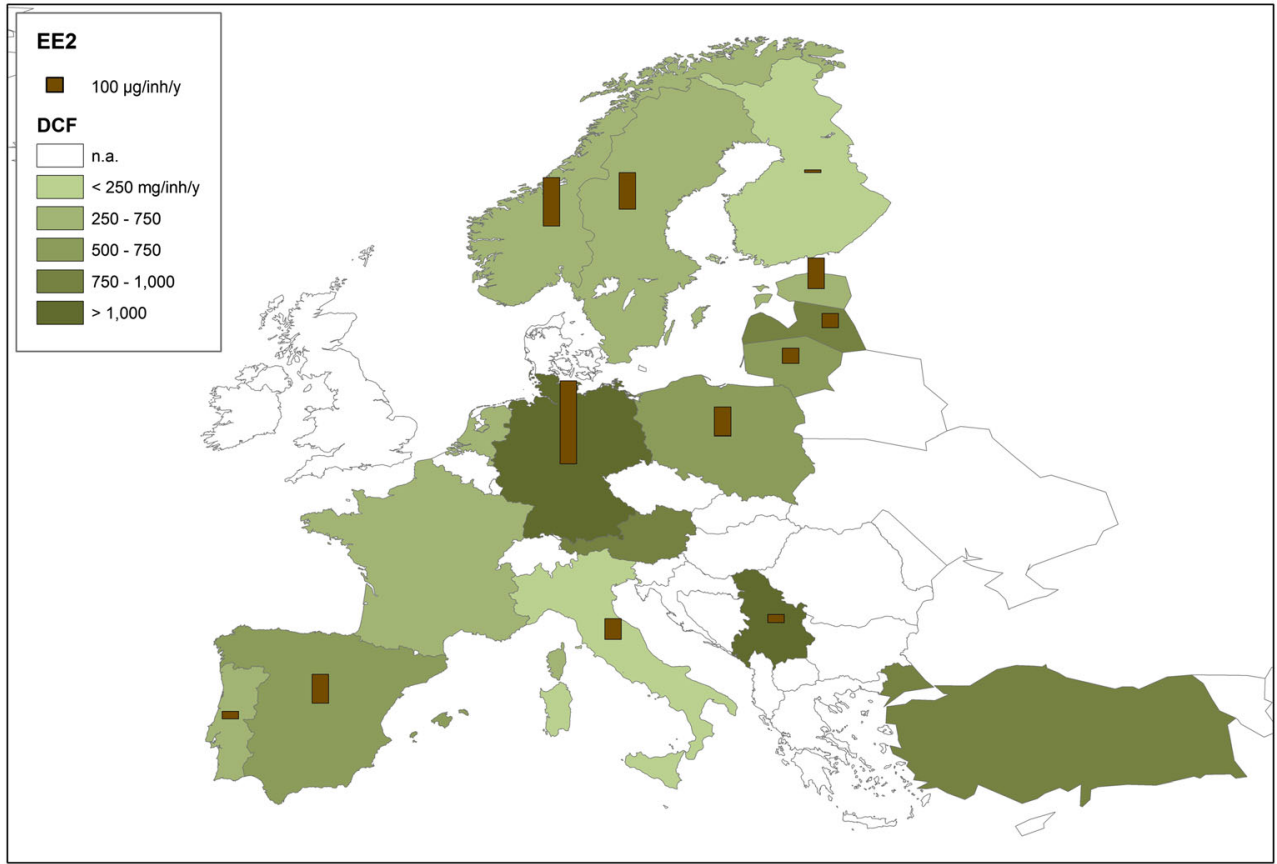

used in many formulations of combined oral contraceptive pills. Both estrogens are detected in WWTPs in the lower nanogram per liter concentrations and are known to cause endocrine-disrupting effects in the biota (Forrez et al. 2009). Again, WWTP effluents are considered the main source of estrogens in the environment (Snyder et al. 2001).

Using these three selected micropollutants from the EU watch list as representatives, the aim of this review is to summarize current problems and solutions in several EU countries and critically evaluate the viability of various treatment methods for the removal of micropollutants from wastewater.

The North Sea Conference on Co-operation in dealing with pollution of the North Sea by oil and other harmful substances (Bonn, 1983), stimulated public awareness to the topic of water quality for the first time. Still, it took almost a decade until the Hague Declaration on the future European Community groundwater policy was ratified at the EC Ministerial Meeting on 26.-27.11.91. Another decade went by until the Agenda 21 requested that quantitative and qualitative discharge standards for municipal and industrial effluents should be established and applied by the year 2000. This recommendation included the proposal to revise Directive 76/ 464/EEC (Dangerous Substances in Water) and the Directive No. 96/61 EC on Integrated Pollution Prevention and Control (IPCC 1996), as well as Directive 93/793/EEC on environmental risk from chemicals (testing the ecotoxicity of listed priority chemicals). Nowadays, updated European framework legislation promotes the reduction of micropollutants. The ETAP (Environmental Technologies Action Plan) of the European Union claims urgent action for better water quality and protection of our natural resources. High priority is also given to environmentally sound water treatment technologies that will reduce greenhouse gases, recycle materials and provide all partner countries with affordable technologies. The discussion paper on water issues is very specific about novel green technologies to be adopted in this respect (http://europa. eu.int/comm/environment/etap/pdfs/etapwaterissuefr.pdf). Substantial political concern exists that water pollutants have to be monitored and removed. However, our knowledge of xenobiotics control or degradation has hardly gone beyond scratching the surface and confirming the importance of the problem. Finally, the EU enhanced the list of dangerous compounds and put estradiols and diclofenac on the Watchlist (Directive 2013/39/EU). The substances (diclofenac and two hormones: $17 \beta$-estradiol (E2) and $17 \alpha$ ethinylestradiol (EE2)) shall be monitored by the EU member states in their surface waters for a maximum of four years. In addition, environmental quality standard values of $100 \mathrm{ng} \mathrm{L}^{-1}$ for inland waters and $10 \mathrm{ng} \mathrm{L}^{-1}$ for coastal water were proposed for diclofenac. Although such political decisions are very helpful to increase the public awareness of water pollution problems, our general behavior towards water protection and water pricing is ambiguous.

\section{National inventories}

The availability of data on the daily use of pharmaceuticals in the EU is scattered and incomplete for recent years. A comprehensive view may be possible for the years between 2005 and 2011 where data from several countries can be compared (Fig. 1). Diclofenac and EE2 consumption rates vary greatly 
between and also within countries. According to literature data in different countries around the world (Ternes 1998; Grung et al. 2007, 2008; Carballa et al. 2005, 2008; Ferrari et al. 2011; INFARMED 2012), the annual consumption of DCF varies between 195 and $940 \mathrm{mg}$ per inhabitant; as for EE2, it varies between 20 and $580 \mu \mathrm{g}$ per inhabitant, respectively. However, in Serbia with a population of 7.2 million in 2012, the annual consumption of DCF and EE2 was equal to 8650 and $0.39 \mathrm{~kg}$ per year, respectively, while the consumption of DCF and EE2 per inhabitant was estimated to be $1197 \mathrm{mg}$ and $50 \mu \mathrm{g}$ per year per inhabitant, respectively (Radonjić and Šipetić 2012). In Germany, for DCF and EE2, respectively, consumption quantities of active ingredients in human medicine were estimated to be $1033 \mathrm{mg}$ and $600 \mu \mathrm{g}$ per inhabitant per year (SRU 2007), while the DCF consumption rate in Turkey for the years 2009 and 2013 was 950 and $985 \mathrm{mg}$ per inhabitant per year, respectively (Sari et al. 2014), and $440 \mathrm{mg}$ per inhabitant and year in The Netherlands (Oosterhuis et al. 2013).

For the calculation of drug consumption in several EU countries for 2011 (Supplemental Table 1), the concept of "defined daily dose" (DDD) was used, i.e., the assumed average maintenance dose per day for a drug used for its main indication in adults expressed as DDD/1000 inhabitants/day, as proposed by the WHO Collaborating Centre for Drug Statistics Methodology (http://www.whocc.no/). Comparing the consumption data, obviously, the DCF and EE2 are among the most popular and most consumed medicine products.

Recent analysis of the consumption of DCF and EE2 in three Baltic States for the 2009-2013 period revealed that the demand for drugs that affect the musculoskeletal system has increased by $4.9 \%$ and the demand for drugs that affect the urogenital system and sex hormones has increased by $9.85 \%$. The sales of diclofenac were equal to $30.3 \%$ of all the sales in accordance with the Anatomical Therapeutic Chemical (ATC) subgroup; the sales of EE2 in its subgroup were equal to $11.6 \%$ (Estonian State Agency of Medicines 2013; Baranauskaite and Dvarioniene 2014).

\section{Occurrence of analgesics and hormones in WWTP's effluents and surface waters}

Various studies over recent years have shown that treated municipal wastewater contributes significantly to water pollution by micropollutants (Hollender et al. 2009; Jelic et al. 2012; Kasprzyk-Hordern et al. 2009; Ternes 1998; Verlicchi et al. 2012). This is a consequence of the increasing number of prescribed medicaments and of the fact that stateof-the-art sewage treatment plants are obviously not designed to remove personal care products and pharmaceuticals (PPCPs) from the wastewater they receive from households and hospitals. DCF, E2, and EE2 have been detected in both WWTPs (influents (WWTP-I) and effluents (WWTP-E)) and surface waters in the range of low microgram per liter to few nanogram per liter levels (Table 1).

One of the first compilations on this topic was a German study detecting diclofenac among 55 pharmaceuticals and 9 of their metabolites in the discharge of 49 sewage treatment plants as well as in their effluents in concentrations of up to several micrograms per liter (Ternes 1998). In the UK, DCF was detected in estuaries at concentrations up to $125 \mathrm{ng} \mathrm{L}^{-1}$ (Thomas and Hilton 2004). Another study reported that 27 out of 32 pharmaceutical substances and 4 of 5 metabolites were detected in the effluents of European wastewater treatment plants and that surface water peak values exceeded $1 \mu \mathrm{g} \mathrm{L}^{-1}$ (Larsen et al. 2004). During an EU-wide monitoring survey on emerging polar organic contaminants in wastewater treatment plant effluents, DCF was found at an average concentration of $49.5 \mathrm{ng} \mathrm{L}^{-1}$, while the highest concentration found was $174 \mathrm{ng} \mathrm{L}^{-1}$ (Loos et al. 2013).

This pollution in the effluents leads to contamination of surface water as has been proven in several novel studies. Levels of target compounds were in the nanogram per liter range but concentrations of some of them exceed $1 \mu \mathrm{g} \mathrm{L}^{-1}$ (including DCF) with fairly high concentrations of $1.3 \mu \mathrm{g} \mathrm{L}^{-1}$ and even $20.1 \mu \mathrm{g} \mathrm{L}^{-1}$, respectively (Petrović et al. 2014), reflecting the consumption of PhACs by the residents of Novi Sad, the second largest town in Serbia. In recent Spanish investigations, DCF seasonal behavior was also monitored north of El Albujón, till the Mar Menor Lagoon into the Mediterranean Sea, where even concentrations of $50 \mathrm{ng} \mathrm{L}^{-1}$ were detected (Moreno-González et al. 2014). Analogously, along the Turia River, which flows into the Mediterranean Sea at some kilometers farther at north than El Albujón, a very consistent amount of DCF was determined (Carmona et al. 2014). In this case, $3500 \mathrm{ng} \mathrm{L}^{-1}$ was detected in the water, whereas a contamination of sediments of $100 \mathrm{ng} \mathrm{g}^{-1}$ was determined.

The Turia case represents an excellent example for the impact on human uses of water contaminated by DCF, considering that water obtained after osmotic treatment, then used as "drinkable" water, still had a concentration of $18 \mathrm{ng} \mathrm{L}^{-1}$ of this pharmaceutical. Concentrations of painkillers and hormones recorded in the aquatic environment during the last decade (2003-2013) are given in Table 1.

As for estrogens, concentrations of $1-500 \mathrm{ng} \mathrm{L}^{-1}$ have been recorded in untreated municipal wastewater, with the distribution of concentrations generally following the pattern E1 $>$ E2 $>$ E3 $>$ EE2 (Racz and Goel 2009). Interestingly, concentrations of 1-500 ng L $\mathrm{L}^{-1}$ have also been reviewed by the same authors in the effluents of wastewater treatment facilities, indicating that elimination of these endocrine substances is insufficient in many if not all treatment systems. 
Table 1 Concentrations of painkillers and hormones recorded in the aquatic environment during the last decade (2003-2013)

\begin{tabular}{|c|c|c|c|c|}
\hline Compound & Type of water & Conc. (ng L ${ }^{-1}$ ) & Country & Citation \\
\hline \multirow[t]{24}{*}{ DCF } & WWTP-E & $\leq 1612$ & Portugal & Salgado et al. (2010) \\
\hline & WWTP-I & $4534-38,674$ & Portugal & Salgado et al. (2012) \\
\hline & WWTP-I & 1020 & Italy & Patrolecco et al. (2013) \\
\hline & WWTP-E & 507 & Italy & Patrolecco et al. (2013) \\
\hline & WWTP-E & 5450 & Italy & Andreozzi et al. (2003) \\
\hline & WWTP-E & $250-5450$ & France, Italy, and Greece & Jiskra (2008) \\
\hline & WWTP-E & 2200 & Germany & Letzel et al. (2009) \\
\hline & WWTP-E & $310-930$ & Switzerland & Jiskra (2008) \\
\hline & WWTP-E & 290 & UK & Thomas and Hilton (2004) \\
\hline & WWTP-E & 125 & UK & Roberts and Thomas (2005) \\
\hline & WWTP-E & 99 & Switzerland & Tixier et al. (2003) \\
\hline & WWTP-E & 91 & UK & Ashton et al. (2004) \\
\hline & WWTP-E & 0.14 & Finland & Bignert et al. (2013) \\
\hline & SW & 261 & UK & Kasprzyk-Hordern et al. (2008) \\
\hline & SW & 140 & Germany & Letzel et al. (2009) \\
\hline & SW & 94 & China & Huang et al. (2011) \\
\hline & SW & 89 & Germany & Heberer (2002b) \\
\hline & SW & $16-65$ & Finland & Bignert et al. (2013) \\
\hline & SW & 35 & Finland & Vulliet et al. (2011) \\
\hline & SW & $10-16$ & Italy & Marchese et al. (2003) \\
\hline & SW & 1.6 & Italy & Loos et al. (2013) \\
\hline & SW & $4-260$ & The Netherlands & RIWA (2014) \\
\hline & SW & $10-120$ & Belgium & RIWA (2014) \\
\hline & GW/DW & 6 & Germany & Heberer (2002b) \\
\hline \multirow[t]{9}{*}{ E2 } & WWTP-I & $\leq 97$ & Portugal & Salgado et al. (2012) \\
\hline & WWTP-I & 64 & Belgium & Forrez et al. (2009) \\
\hline & WWTP-E & $15-27$ & Germany & Carballa et al. (2004) \\
\hline & WWTP-E & 17 & USA & Wright-Walters and Volz (2007) \\
\hline & WWTP-E & $<10$ & Sweden & Bigner et al. (2013) \\
\hline & SW & 9.5 & Italy & Pojana et al. (2007) \\
\hline & SW & 9 & Italy & Viganò et al. (2008) \\
\hline & SW & 1 & Italy (Rome) & Baronti et al. (2000) \\
\hline & SW & $<1$ & The Netherlands & RIWA (2014) \\
\hline \multirow[t]{7}{*}{ EE2 } & WWTP-I & $\leq 39$ & Portugal & Salgado et al. (2012) \\
\hline & WWTP-I & 106 & Belgium & Forrez et al. (2009) \\
\hline & WWTP-E & $<1$ & Spain & Carballa et al. (2004) \\
\hline & WWTP-E & 0.04 & Sweden & Bigner et al. (2013) \\
\hline & SW & 11 & Italy & Pojana et al. (2007) \\
\hline & SW & 0.04 & Italy (Rome) & Baronti et al. (2000) \\
\hline & SW & $<500$ & The Netherlands & RIWA (2014) \\
\hline
\end{tabular}

$W W T P-I$ wastewater treatment plant influent, $W W T P-E$ wastewater treatment plant effluent, $S W$ surface water, $D W$ drinking water, $G W$ groundwater

\section{Progress in detection and identification}

The detection and identification of PPCPs in environmental samples can be divided into three categories, namely quantitative targeted analysis employing reference standards, suspects screening without reference standards, and nontargeted screening (Krauss et al. 2010; Kind and Fiehn 2010; Little et al. 2011). Quantitative target analysis is the 
most common approach, in which only a number of previously selected, and often regulated, compounds are determined and the method is only validated for such compounds. For the monitoring of the target compounds DCF, EE2, and E2 in water samples, preconcentration is required prior to analysis. Currently, solid-phase extraction (SPE) is the most widely used procedure to extract and concentrate pharmaceuticals and other organic pollutants from environmental samples. In the specific case of DCF, acidification of the aqueous sample is frequently used to facilitate more efficient recovery of the target molecule from natural samples (Table 2). When the adopted analytical technique is based on gas chromatography (GC) coupled with mass spectrometry (GC-ion trap-MS/MS, GC-MS, or GC-MS-SIM), derivatization is necessary (methylation, terbutylation, etc.) to enable separation and detection. These operations are not necessary when final analysis is performed with LC-MS/MS. In any case, pretreatment and derivatization will enhance the overall difficulty of the analysis, and its final net cost for the respective additional preparative works, without a significant difference in terms of limits of quantification (LOQ). Consequently, and specifically since coelution occurs, several labs have proposed to omit this preconcentration step and begun to search for other solutions.

Often there is lack of information on analyzed samples because only user-defined MS/MS transitions are saved in the method and compounds in the sample that are not specified beforehand remain unknown. Employment of the MS/MS techniques for quantitative target analysis has also some drawbacks and limitations, namely (i) methods are typically limited to about 100 150 target compounds depending on chromatographic separation under the constraints of having at least two transitions per compound; (ii) for some compounds, only nonspecific transitions might occur such as the neutral loss of $\mathrm{H}_{2} \mathrm{O}$ or $\mathrm{CO}_{2}$, which are also common for matrix interferences; and (iii) for some analytes, especially those of low molecular weight, only one transition is present.

When analyzing sewage sludge, an additional step is necessary for exhaustive determination of DCF, E2, and EE2. Namely, the first step in pretreatment usually applied involves extraction of the target compounds from a solid sample by pressurized liquid extraction (PLE, Radjenović et al. 2009), microwave assisted extraction (MAE, Cortazar et al. 2005; Rice and Mitra 2007), or ultrasound sonification (US, Gatidou et al. 2007). In addition, an extensive cleaning of the obtained extract to avoid any matrix interference will remove organic and inorganic coextractives, before they might interfere with analyte separation and detection causing background noise in GC-MS analysis and signal suppression and/ or enhancement in LC-MS analysis.

After application of one of the mentioned extraction techniques (PLE, MAE, or US) as the first pretreatment step to solid matrices, the next steps involved are presented in Table 2. Which of the listed methodologies will be selected depends on the type of analyte and particular techniques available in the laboratory.

In Table 2, the main published procedures for analyzing DCF, E2, and EE2 in environmental water samples are compiled. It becomes clear that for both DCF and the estrogen determination by GC-MS necessarily involves an additional derivatization step (e.g., by methylation, tert-butyldimethylsilyl, with N-methyl$\mathrm{N}$-(trimethylsilyl)trifluoroacetamide, etc.) due to the polarity of the compounds. Determination by LC-MS is indeed simpler and can even be automated provided that an online SPE can be used to reach the low detection limits that are frequently required (Patrolecco et al. 2013).

Another issue worth considering is the presence in environmental aqueous samples, together with target pharmaceutical compounds, of other compounds that are practically linked to the selected targets, namely metabolites and transformation products (TP). The determination of such compounds is not straightforward due to the lack of relevant mass spectrometric data available in LC-MS/MS methods, namely the precursor ion mass, the product ion masses (quantifier ion and qualifier ion), and the collision energy voltage. Therefore, an approach that is not based on the selectivity of the MS/MS mode but that employs high-resolution MS (HRMS) allowing the detection in scan mode would be much more beneficial.

In nontarget screening analysis, unknown components in the sample chromatogram are extracted from tentatively identified compounds (TIC), using special deconvolution software that detects the ions filtering them out from the background. For this type of experiment, the employment of HRMS(/MS) is reported to be the only effective technique to be used (Krauss et al. 2010; Nurmi et al. 2012; Godfrey and Brenton 2012). Indeed, a structure proposition for a peak detected by HRMS and MS/MS spectra involves several work-intensive data and expert processing steps (Krauss et al. 2010; Nurmi et al. 2012; Kind and Fiehn 2010; Little et al. 2011, 2012; Amorisco et al. 2013).

It is evident that nontarget screening analysis is incapable of revealing all compounds in the sample, causing possible false negative results. This is due to the inherent nature of LC-MS analysis, since both, chromatography and ionization always exclude some of the compounds. As a very useful evaluation tool for possible candidates, HRMS is ideal when combined subsequently with a powerful structure elucidation technique like nuclear magnetic resonance spectroscopy (NMR, De Laurentiis et al. 2014). An efficient modern method for both target and nontarget screening analysis for DCF is the hyphenation of hydrophilic interaction chromatography (HILIC) with RPLC coupled with highly accurate MS, such as TOF-MS. 
Table 2 Relevant information related to preconcentration steps and analysis of environmental water samples for diclofenac, E2, and EE2 determination. Costs listed refer to the different analytical options, without considering those related to instrument investment or the possibility, for each method, to be capable of determining several compounds simultaneously (multiresidual analysis). In any case, limiting the determination only to a restricted number of target compounds could be considered a too simplistic approach which might not be useful to fully take advantage of the potentialities of the instrumentation nowadays available

\begin{tabular}{|c|c|c|c|c|c|c|c|}
\hline Sample & $\begin{array}{l}\text { Preparation } \\
\text { steps }\end{array}$ & $\begin{array}{l}\text { Recovery } \\
(\%)\end{array}$ & $\begin{array}{l}\text { Analytical } \\
\text { technique }\end{array}$ & $\begin{array}{l}\mathrm{LOQ} \\
\left(\mu \mathrm{g} \mathrm{L}^{-1}\right)\end{array}$ & $\begin{array}{l}\text { Analysis } \\
\text { time and } \\
\text { difficulty }^{\mathrm{a}}\end{array}$ & $\begin{array}{l}\text { Analysis } \\
\text { costs } \\
(€ / \text { sample })^{\mathrm{b}}\end{array}$ & Reference \\
\hline \multicolumn{8}{|l|}{ Diclofenac } \\
\hline Wastewater influent and effluent & $\begin{array}{l}\text { 1. Filtration } \\
\text { 2. SPE preconcentration } \\
\text { 3. Derivatization }\end{array}$ & 100 & GC-MS/MS & 0.05 & ++ & $40-60$ & $\begin{array}{l}\text { Carballa et al. } \\
\qquad(2004,2005,2007)\end{array}$ \\
\hline $\begin{array}{l}\text { raw industrial and municipal } \\
\text { wastewater, surface, ground, } \\
\text { drinking water }\end{array}$ & $\begin{array}{l}\text { 1. Acidification } \\
\text { 2. SPE pre-concentration } \\
\text { 3. IS addition }\end{array}$ & $55-116$ & LC-ESI-MS/MS & $0.012-0.02$ & ++ & $30-50$ & $\begin{array}{l}\text { Gros et al. (2006a, b, } \\
\text { 2009, 2012), } \\
\text { Petrović et al. } \\
\text { (2014) }\end{array}$ \\
\hline $\begin{array}{l}\text { Wastewater influent and effluent, } \\
\text { groundwater }\end{array}$ & $\begin{array}{l}\text { 1. Filtration } \\
\text { 2. SPE preconcentration } \\
\text { 3. Derivatization }\end{array}$ & $55-100$ & GC-MS & 0.025 & +++ & $40-60$ & $\begin{array}{l}\text { Ternes (1998, 2001), } \\
\text { Ternes et al. (2003) }\end{array}$ \\
\hline $\begin{array}{l}\text { Wastewater influent and effluent, } \\
\text { basin water }\end{array}$ & $\begin{array}{l}\text { 1. Acidification } \\
\text { 2. IS addition } \\
\text { 3. SPE preconcentration }\end{array}$ & 100 & LC/ESI-MS/MS & $>0.03$ & ++ & $30-50$ & $\begin{array}{l}\text { Sacher et al. (2008), } \\
\text { Oosterhuis et al. } \\
(2013)\end{array}$ \\
\hline Wastewater influent and effluent & $\begin{array}{l}\text { 1. Acidification } \\
\text { 2. IS addition } \\
\text { 3. SPE preconcentration }\end{array}$ & 100 & $\begin{array}{l}\text { UHPLC-MS/ } \\
\text { MS }\end{array}$ & $0.05-0.14$ & ++ & $30-50$ & $\begin{array}{l}\text { Gracia-Lor et al. } \\
\quad(2010,2011)\end{array}$ \\
\hline River water, WWTP effluent & $\begin{array}{l}\text { 1. Addition of deuterated } \\
\text { standards } \\
\text { 2. Acidification } \\
\text { 3. SPE preconcentration } \\
\text { 4. IS addition }\end{array}$ & 99 & LC/ESI/MS & 0.02 & ++ & & Letzel et al. (2009) \\
\hline Wastewater influent and effluent & $\begin{array}{l}\text { 1. Acidification } \\
\text { 2. SPE preconcentration } \\
\text { 3. Derivatization }\end{array}$ & $65-85$ & $\begin{array}{l}\text { GC/ion } \\
\text { trap-MS/MS }\end{array}$ & 0.12 & ++ & $40-60$ & Serrano et al. (2011) \\
\hline $\begin{array}{l}\text { River, wastewater influent } \\
\text { and effluent }\end{array}$ & $\begin{array}{l}\text { 1. Filtration } \\
\text { 2. SPE preconcentration } \\
\text { 3. Derivatization }\end{array}$ & $56-112$ & $\begin{array}{l}\text { UHPLC-MS/ } \\
\text { MS }\end{array}$ & $0.006-0.012$ & +++ & $40-60$ & Huang et al. (2011) \\
\hline \multicolumn{8}{|l|}{ E2 and EE2 } \\
\hline Surface water and wastewater & $\begin{array}{l}\text { 1. Filtration }(1.5 \mu \mathrm{m}) \\
\text { 2. SDB-XC disk extraction } \\
\text { 3. SPE }(\mathrm{C} 18 \text { and NH2) } \\
\text { 4. HPLC elution } \\
\text { 5. Derivatization }\end{array}$ & $88-92$ & $\begin{array}{l}\text { GC/ion } \\
\text { trap-MS/MS }\end{array}$ & $0.1-2.4$ & +++ & $40-60$ & Belfroid et al. (1999) \\
\hline $\begin{array}{l}\text { Wastewater influent and } \\
\text { effluent, rivers }\end{array}$ & $\begin{array}{l}\text { 1. Filtration }(1.5 \mu \mathrm{m}) \\
\text { 2. SPE preconcentration } \\
\text { 3. Addition of IS }\end{array}$ & $80-92$ & LC/ESI-MS/MS & $0.008-0.8$ & ++ & $30-50$ & Baronti et al. (2000) \\
\hline $\begin{array}{l}\text { Wastewater influent and effluent, } \\
\text { anaerobic digester influent } \\
\text { and effluent }\end{array}$ & $\begin{array}{l}\text { 1. Filtration }(1.5 \mu \mathrm{m}) \\
\text { 2. SPE purification/ } \\
\text { preconcentration } \\
\text { 3. Derivatization }\end{array}$ & $82-84$ & $\begin{array}{l}\mathrm{GC} / \text { ion } \\
\text { trap-MS/MS }\end{array}$ & 1 & +++ & $40-60$ & $\begin{array}{l}\text { Ternes (1998), } \\
\quad \text { Carballa et al. } \\
\quad(2004,2005,2007)\end{array}$ \\
\hline $\begin{array}{l}\text { Synthetic, wastewater influent } \\
\text { and effluent, surface waters }\end{array}$ & $\begin{array}{l}\text { 1. Filtration }(1.5 \mu \mathrm{m}) \\
\text { 2. } \mathrm{MeOH} \text { and IS addition } \\
\text { 3. SPE purification/ } \\
\text { preconcentration } \\
\text { 4. Derivatization }\end{array}$ & $79-100$ & $\begin{array}{l}\text { GC/ion } \\
\text { trap-MS/MS }\end{array}$ & $3-20$ & +++ & $40-60$ & Quintana et al. (2004) \\
\hline $\begin{array}{l}\text { Surface water, wastewater } \\
\text { influent and effluent }\end{array}$ & 1. Filtration & $65-105$ & LC/LC-MS/MS & $0.002-0.003$ & +++ & $20-40$ & Gorga et al. (2013) \\
\hline
\end{tabular}

a +: low, ++ : moderate, +++ : high

${ }^{\mathrm{b}}$ Analysis cost was estimated including the cost of the column (lasting about 500 injections) and SPE cartridge and amortization of instrumentation (lasting 5 years)

With the set of detection methods discussed here, the analyst has a powerful tool for comprehensive and simultaneous analysis of compounds in a wide range of polarity, including the estrogens, DCF, and their transformation products (Rajab et al. 2013).

\section{Conventional treatment systems and their shortcomings}

Conventional WWTPs are designed to limit the discharges of organic carbon, nitrogen, phosphorus, and pathogens to the 
aquatic environment. To do so, WWTPs apply a primary, a secondary, and an optional tertiary treatment process. During primary treatment, coarse solids are separated from the liquid stream and micropollutants are removed mainly by chemical and mechanical separation. The sorption of micropollutants onto solids depends basically on their physicochemical properties, such as lipophilicity or acidity. Two types of coefficients have been mostly used to determine the sorption effectiveness: the octanol-water partition coefficient $\left(K_{\text {ow }}\right)$ and the organic carbon partition coefficient $\left(K_{\mathrm{oc}}\right)$. $\log K_{\mathrm{ow}}<2.5$ indicates a low sorption potential, $2.5<\log K_{\mathrm{ow}}<4$ indicates a medium sorption potential, while $\log K_{\mathrm{ow}}>4$ indicates a high sorption potential (Rogers 1996). However, some limitations have been found in the literature (Holbrook et al. 2004; Lai et al. 2000) for the applicability of these coefficients to explain the sorption behavior of some micropollutants, because acidity determined by functional groups also plays a significant role in sorption behavior. Therefore, the solid-water distribution coefficient $\left(K_{\mathrm{d}}\right)$, defined as the ratio between the concentrations of a substance in the solid and in the aqueous phase at equilibrium conditions, has been proposed as the most suitable parameter (Schwarzenbach et al. 2003; Ternes et al. 2004a, b; Joss et al. 2005). This coefficient takes into account the two main sorption mechanisms absorption (hydrophobic interactions characterized by the $K_{\text {ow }}$ value, relevant for neutral compounds) and adsorption (electrostatic interactions related to the substance tendency to be ionized or dissociated in aqueous phase, characterized by the dissociation constant, $\mathrm{p} K_{\mathrm{a}}$ ). At $\mathrm{pH}$ above the $\mathrm{p} K_{\mathrm{a}}$, phenolic hydroxyl or carboxyl groups dissociate and become negatively charged (Schäfer et al. 2011). DCF, for example, with a $K_{\mathrm{a}}>4$ is negatively charged in municipal WWTP effluents, while E2 and EE2 are still in their neutral form. Table 3 summarizes these properties for the compounds under consideration. It can be observed that the three substances show a medium tendency to sorb onto solids, and consequently, only intermediate removal (20-45\%) has been obtained during primary treatment (Carballa et al. 2005; Behera et al. 2011).

The most commonly applied secondary treatment in WWTPs is the conventional activated sludge process (CAS), where both organic matter and nutrients are biologically removed. In this step, removal of a parent compound occurs by different mechanisms: a) stripping by aeration; b) sorption to particles or biomass; and c) biotransformation/biodegradation. Stripping is not significant for DCF, EE2 or E2 due to their high molecular mass and therefore low volatility (Radjenović et al. 2009). As described in the previous paragraph, sorption to sewage sludge is moderate, and therefore, biological transformation is the most likely mechanism responsible for micropollutant elimination in WWTPs. Although the microbiota developed in WWTPs may have been exposed to a plethora of micropollutants for a long time, the effective biological removal of these substances is conditioned by singular factors. Some of these factors are micropollutant-related, such as chemical structure or functional groups. In general, linear compounds with short side chains, unsaturated aliphatic compounds, and compounds possessing electron donating functional groups are easily degradable (Luo et al. 2014). The biodegradability of organic compounds is commonly classified according to their kinetic reaction rate $\left(k_{\mathrm{biol}}\right)$. Suarez et al. (2010) have defined four groups of substances according to their biodegradability based on grams of suspended solids (ss) and days:

- Very highly degradable: $k_{\text {biol }}>5 \mathrm{~L} /\left(\mathrm{g}_{\mathrm{ss}}\right.$ day)

- Highly degradable: $1<k_{\text {biol }}<5 \mathrm{~L} /\left(\mathrm{g}_{\text {ss }}\right.$ day)

- Moderate degradable: $0.5<k_{\text {biol }}<1 \mathrm{~L} /\left(\mathrm{g}_{\mathrm{ss}}\right.$ day)

- Hardly degradable: $k_{\text {biol }}<0.5$

From the data compiled in Table 3, only E2 and EE2 can be identified as very highly degradable, while DCF is very recalcitrant. However, it should be considered that these degradation

Table 3 Molecular properties of the compounds under consideration

\begin{tabular}{|c|c|c|c|c|c|c|}
\hline Compound & $\begin{array}{l}\text { Molecular weight } \\
\left(\mathrm{g} \mathrm{mol}^{-1}\right)\end{array}$ & Molecular width $(\AA)$ & $\log K_{\mathrm{ow}}$ & $\mathrm{p} K_{\mathrm{a}}$ & $\log K_{\mathrm{d}}$ & $\begin{array}{l}k_{\text {biol }} \text { for CAS } \\
\left.\mathrm{L} / \mathrm{g}_{\mathrm{ss}} \text { day }\right)\end{array}$ \\
\hline DCF & 296.2 & $5.95^{\mathrm{a}}$ & $4.5-4.8^{\mathrm{a}, \mathrm{b}}$ & $4.0-4.5^{\mathrm{b}}$ & $1.2^{\mathrm{c}}-2.1^{\mathrm{d}}$ & $\leq 0.1^{\mathrm{e}}$ \\
\hline E2 & 272.4 & $5.21^{\mathrm{a}}$ & $3.9-4.0^{\mathrm{a}, \mathrm{f}}$ & 10.4 & $2.5-3.5$ & $300-800$ \\
\hline EE2 & 296.4 & & $2.8-4.2^{\mathrm{f}}$ & $10.5-10.7$ & $2.3-2.8^{\mathrm{c}}$ & $7-9^{\mathrm{g}}$ \\
\hline
\end{tabular}

\footnotetext{
${ }^{a}$ Drewes et al. (2005)

${ }^{\mathrm{b}}$ Yang et al. (2011)

${ }^{\mathrm{c}}$ Ternes et al. (2004a, b)

${ }^{\mathrm{d}}$ Radjenović et al. (2009)

e Joss et al. (2006)

${ }^{\mathrm{f}}$ Schäfer et al. (2011)

${ }^{\mathrm{g}}$ Suárez et al. (2008)
} 
constants are usually determined in lab-scale experiments and the operational conditions in WWTPs might be different. In fact, there is evidence that some operating parameters, such as hydraulic retention time (HRT), solid retention time (SRT), redox conditions, and temperature may affect micropollutant removal. HRT is the time that allows for biodegradation and sorption (Luo et al. 2014). Micropollutants having slow/intermediate kinetics will experience less effective biotransformation at shorter HRT or increasing loading rates (Fernandez-Fontaina et al. 2012). However, for E2 and EE2, the effect of this parameter is minor. Extended SRT, facilitating the buildup of slowly growing microbes, such as nitrifying bacteria, will enhance the elimination of micropollutants (Clara et al. 2005; Suarez et al. 2010, 2012; Silva et al. 2012; Luo et al. 2014), but beyond 25-30 days, this parameter is not significant anymore. This influence is clear for E2 and EE2, but contradictory results have been published for DCF. According to the findings of Joss et al. (2005), the elimination rates of DCF did not improve even when extreme SRT (more than 60 days) was applied. In contrast, promoted removal rates for DCF with increasing SRT were reported by Nikolaou et al. (2007), Stasinakis et al. (2010), Falas et al. (2012), Fernandez-Fontaina et al. (2012), and Falas et al. (2013). However, extremely high SRT ( $>150$ days) is unrealistic in conventional WWTPs with activated sludge process. Regarding redox conditions, different removal efficiencies have been observed for anaerobic, anoxic, and aerobic conditions (Joss et al. 2004). Overall, aerobic conditions are preferable for estrogen removal (Silva et al. 2012), while anoxic and anaerobic conditions might be slightly better for DCF (Zwiener and Frimmel 2003; Vieno and Sillanpää 2014). Finally, higher temperatures positively influence the removal of micropollutants, as shown for example in Ternes et al. (1999) when comparing the removal efficiencies of estrogens in a German and a Brazilian WWTP.

To sum up, conventional WWTPs have not been designed for micropollutant elimination and have therefore only limited capacity to remove DCF, E2, and EE2. During recent years, various studies have demonstrated this shortcoming and pointed out that treated municipal wastewater even contributes significantly to water pollution (see Table 4). In order to minimize micropollutant discharges into the environment, existing wastewater treatment processes must be upgraded with advanced and alternative methods.

\section{Advanced and alternative methods}

\section{Mechanical-physical methods}

\section{Membrane filtration}

Microfiltration (MF) and ultrafiltration (UF) are suitable to decrease the concentrations of pharmaceuticals by improved retention of suspended solids in which the more hydrophobic/ neutral pharmaceuticals are adsorbed. Hydrophilic substances which are not adsorbed to sludge cannot be retained by $\mathrm{MF}$ and UF because of the pore sizes (MF 100-5000 nm, UF 10$100 \mathrm{~nm}$ ) (Joss et al. 2005). Nanofiltration (NF) and reverse osmosis (RO) have much tighter structures (NF 1-10 nm and RO 0.1-1 nm). In NF and RO membrane processes, the rejection of organic micropollutants like DCF, E2, and EE2 can generally be achieved by size exclusion/steric hindrance, adsorption onto membrane, and/or charge repulsion (Bellona et al. 2004; $\mathrm{Xu}$ et al. 2006). The removal efficiency (Table 5) is dependent on properties of the target compound (e.g., molecular weight (MW), molecular diameter (MWd), $\mathrm{p} K_{\mathrm{a}}$, hydrophilicity/hydrophobicity $\left(\log K_{\mathrm{ow}}\right)$, and diffusion coefficient) and membrane properties. Key membrane properties affecting rejection are pore size, molecular weight cutoff (MWCO), surface charge (measured as zeta potential), hydrophilicity/hydrophobicity, and surface morphology (measured as surface roughness). Additionally, operation conditions like $\mathrm{pH}$ value, ionic strength, hardness, the presence of organic matter, and membrane fouling influence the rejection of organic micropollutants (Bellona et al. 2008; Xu et al. 2006; Schäfer et al. 2011). Membrane operation conditions as well as hydrodynamic conditions, such as feedwater recovery, concentration polarization, and feedwater velocity, have been found to influence the rejection of organic micropollutants. Concentrations in influent and effluents and the removal efficiency by advanced biological methods are given in Table 5 .

In general, if the MW of an organic compound is larger than MWCO of the membrane, the rejection of the compound can be expected to be very high because of steric and electrostatic exclusion. Especially for compounds with a $\log K_{\mathrm{ow}}<2$, rejection is governed by MWd compared to the pore size of the membrane. The $\mathrm{pH}$ value has a strong influence on the retention of DCF, since the retention of ion species is higher than that of neutral solutes in nanofiltration (Bellona et al. 2004). At lower $\mathrm{pH}$ range, where the acidic pharmaceuticals are neutral, larger molecules gave higher retention, because size is the most important parameter in nanofiltration (Urase and Sato 2007).

Table 6 shows the percentage of rejection determined for DCF, E2, and EE2 by different authors along with the type of membrane applied.

A study by Nghiem et al. (2005) observed that, in the presence of organic matter, micropollutant retention (e.g., hormones) was favored. A clear $\mathrm{pH}$ dependency was also found by these authors. As the $\mathrm{pH}$ value decreases in the water matrix, the amount of humic acids adsorbed on the membrane increased, as well as the adsorption of the endocrine substances. Koyuncu et al. (2008) explained this by the formation of macromolecular complexes, resulting from the association of humic acids with the hormones. This leads to an increase of size and may enhance the size exclusion effect and the adsorption of hormones onto membranes (Silva et al. 2012). 


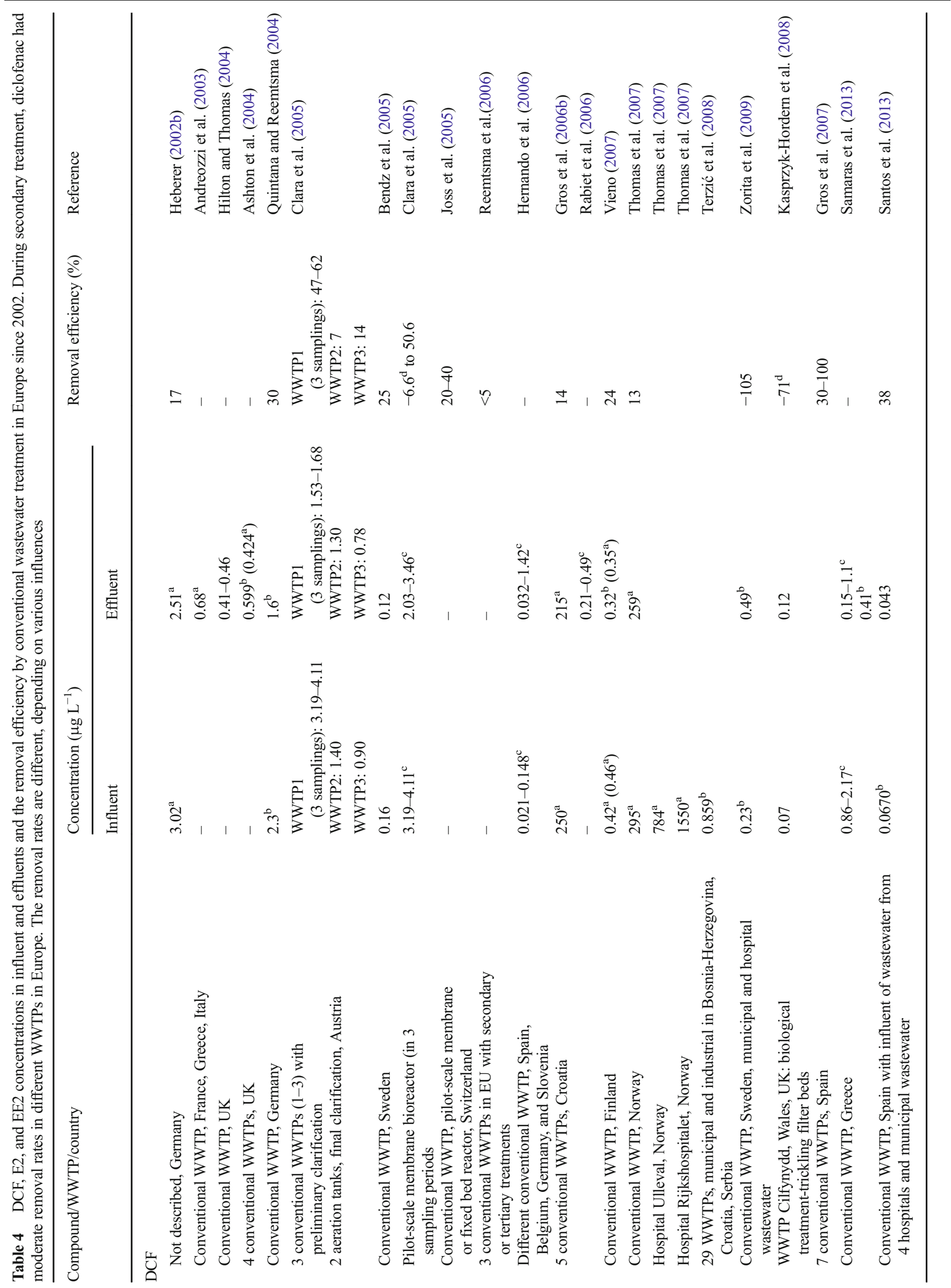




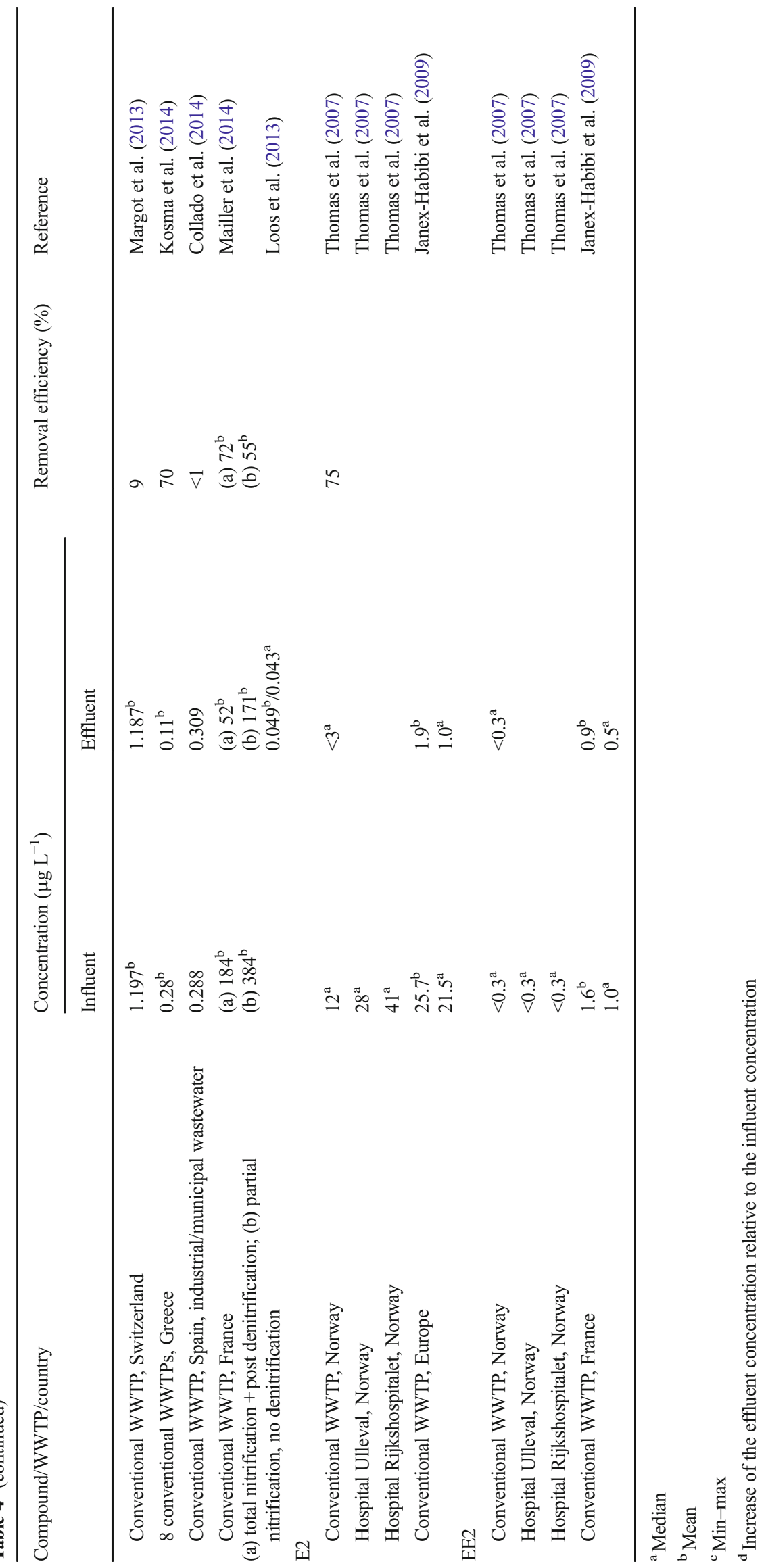


Table 5 Concentrations in influent and effluents and the removal efficiency by advanced biological methods

\begin{tabular}{llll}
\hline Treatment process & SRT (days) & Removal efficiency (\%) & Reference \\
\hline Diclofenac & & & Kruglova et al. (2014) \\
$\quad$ Full-scale WWTP & $14-16$ & 68 & Ribeiro et al. (2013) \\
$\quad$ Lab-scale SBR & $10-12$ & 90 & Quintana et al. (2005) \\
Lab-scale MBR & 37 & 23 & Abegglen et al. (2009) \\
$\quad$ Single-house MBR & $>100$ & 103 & Tadkaew et al. (2011) \\
$\quad$ Lab-scale MBR, synthetic WW, HRT 24 h & 70 & 17.3 (mean) \\
E2 & 70 & $>99.4$ & Tadkaew et al. (2011) \\
$\quad$ Lab-scale MBR, synthetic WW, HRT 24h & $>100$ & & Abegglen et al. (2009) \\
EE2 & 70 & 93.5 (mean) & Tadkaew et al. (2011) \\
$\quad$ Single-house MBR & & & \\
Lab-scale MBR, synthetic WW, HRT 24h & & & \\
\hline
\end{tabular}

$M B R$ membrane bioreactor, $H R T$ hydraulic retention time, $S B R$ sequential bioreactor; $W W$ wastewater, $W W T P$ wastewater treatment plant

Röhricht et al. (2009) investigated two different types of submerged nanofiltration flat sheet modules for the removal of pharmaceuticals from WWTP effluents. It was shown that DCF was retained up to $60 \%$. At $\mathrm{pH} 8$, DCF ( $\mathrm{p} K_{\mathrm{a}}$ value of 4.15) was deprotonated and could be rejected by the negatively charged membrane surface. This was in accordance with the statement pointed out by Nghiem et al. (2005) indicating that speciation of pharmaceuticals may result in significant change in rejection as a function of $\mathrm{pH}$, with much greater retention for ionized, negatively charged molecules. When reverse osmosis was applied after conventional activated sludge-ultrafiltration (CAS)-UF/RO and membrane bioreactor MBR/RO, Sahar et al. (2011) reported relatively similar and high elimination of $95 \%$ for DCF in both processes. Despite the highly effective RO treatment, DCF was found in permeates from both units indicating that $\mathrm{RO}$ could not completely eliminate this compound and that the additional process was necessary.
Table 6 Rejection of DF, E2, and EE2 by membrane filtration

\begin{tabular}{|c|c|c|c|}
\hline Compound & Membrane type & Rejection $(\%)^{\mathrm{a}}$ & Reference \\
\hline \multirow[t]{5}{*}{ Diclofenac } & $\mathrm{NF}$ & 100 & Radjenović et al. (2009) \\
\hline & RO & 100 & Radjenović et al. (2009) \\
\hline & $\mathrm{NF}$ & 60 & Röhricht et al. (2009) \\
\hline & $\mathrm{NF}$ & 65 & Röhricht et al. (2010) \\
\hline & $\mathrm{MBR} / \mathrm{RO}$ & 95 & Sahar et al. (2011) \\
\hline \multirow[t]{10}{*}{ E2 } & RO & 83 & Kimura et al. (2007a, b) \\
\hline & $\mathrm{NF} / \mathrm{RO}$ & 90 & Nghiem et al. (2005) \\
\hline & $\mathrm{NF}$ & $>99$ & Weber et al. (2004) \\
\hline & $\mathrm{NF}$ & $>95$ & Yoon et al. (2007) \\
\hline & $\mathrm{RO} / \mathrm{NF}$ & High & Drewes et al. (2005) \\
\hline & $\mathrm{NF}$ & 77 & Bodzek and Dudziak (2006) \\
\hline & DCMD & $\geq 99.5$ & Cartinella et al. (2006) \\
\hline & $\mathrm{NF}$ & 100 & Koyuncu et al. (2008) \\
\hline & $\mathrm{NF} / \mathrm{RF}$ & 100 & Alturki et al. (2010) \\
\hline & $\mathrm{NF}$ & 100 & McCallum et al. (2008) \\
\hline \multirow[t]{4}{*}{ EE2 } & $\mathrm{NF}$ & $>99$ & Weber et al. (2004) \\
\hline & $\mathrm{NF}$ & 90 & Dudziak and Bodzek (2009) \\
\hline & $\mathrm{NF}$ & 60 & Yoon et al. (2007) \\
\hline & $\mathrm{NF} / \mathrm{RO}$ & 99 & Alturki et al. (2010) \\
\hline
\end{tabular}

$N F$ nanofiltration, $R O$ reverse osmosis, $M B R$ membrane bioreactor, $D C M D$ direct contact membrane distillation ${ }^{\text {a }}$ Under optimal conditions 
One drawback of NF and RO is membrane fouling which may influence the performance of the process as a whole by causing a noticeable decrease in the rejection of organic micropollutants ( $\mathrm{Ng}$ and Elimelech 2004).

Special types of membrane filtration are direct contact membrane distillation (DCMD) and forward osmosis (FO) which were investigated by Cartinella et al. (2006) for the rejection of hormones. With these techniques, high rejection of over $99.5 \%$ was observed.

The overall conclusion is that membrane filtration is promising, but has not yet been established to provide stable and complete operation at technical scale. There is still great need for research.

\section{Adsorption onto sorption materials}

Over the years, adsorption has been considered one of the most effective methods to eliminate pollutants from contaminated water (Table 7). Adsorption elimination is based on the uptake of pollutants from the aqueous phase onto a solid phase (sorbent). The affinity of a target compound for its sorbent is often quantified by the specific sorption coefficient, representing the ratio of sorbed and dissolved concentrations of a target compound in equilibrium (Silva et al. 2012). Especially activated carbon (AC) is a well-studied sorbent. In Europe, the most commonly applied ACs are powdered activated carbon (PAC, 5-50 $\mu \mathrm{m}$ diameters) and granular activated carbon (GAC, 100-2400 $\mu \mathrm{m}$ diameters). Table 7 lists different studies concerning the removal of DCF, E2, and EE2 from aqueous solution and WWTP effluents. Zhang et al. (2007) reported that the adsorption process onto $\mathrm{AC}$ is strongly influenced by environmental conditions. Contact time has a major effect on removal efficiency. Short contact is likely to lead to significantly lowered adsorption efficiency (Luo et al. 2014). Kumar and Mohan (2011) demonstrated that the adsorption capacity of WWTP effluents is maximum at neutral conditions and at temperatures of up to $30{ }^{\circ} \mathrm{C}$. Sorption of micropollutants onto $\mathrm{AC}$ may be reduced by the amount of organic matter and other substances, which are also present in the water matrix because they compete for AC adsorption sites (Fukuhara et al. 2006; Kumar and Mohan 2011; Snyder et al. 2007; Zhang and Zhou 2005). Grover et al. (2011) showed removal efficiencies for DCF, EE2, and E2 of $>98 \%$ in a full-scale granular activated carbon plant treating WWTP effluent. The efficiency of GAC-based removal will decrease over time due to saturation of adsorption sites. Therefore, reactors based on GAC have to be operated with care (Luo et al. 2014).

On the technical scale, PAC is added to WWTP either directly into the activated sludge process or in a subsequent process and needs to be separated from the treated wastewater after application. This is achieved by sedimentation under the addition of flocculation agents or ultrafiltration or sand filtration (Margot et al. 2013). These authors reported mean removal efficiency with GAC/UF combination of $69 \%$. However, PAC adsorption, with a dosage of $10-20 \mathrm{mg} \mathrm{L}^{-1}$, has been proposed as a more efficient alternative compared to GAC treatment (Boehler et al. 2012; Nowotny et al. 2007; Serrano et al. 2011).

The main advantage of using $\mathrm{AC}$ to remove micropollutants is that it does not generate toxic or pharmacologically active products (Rivera-Utrilla et al. 2013). The addition of PAC or GAC could also enhance the removal efficiency of micropollutants during biological treatment. Serrano et al. $(2010,2011)$ reported a significant improvement of DCF removal by adding $1 \mathrm{mg} \mathrm{L}^{-1}$ PAC to an MBR treating municipal wastewater and of $0.5 \mathrm{mg} \mathrm{L}^{-1} \mathrm{GAC}$ to a conventional activated sludge treatment.

Apart from AC, several other sorbent materials have been studied to remove DCF, E2, and EE2. Zhang and Zhou (2005) used chitin, chitosan, an ion-exchange resin, and a wastederived carbonaceous adsorbent for the removal of E2, but the sorption capacity was lower than with GAC. Another studied sorbent is steroid-based imprinted polymer (molecularly imprinted polymer, MIP). Different groups studied the adsorption of E2 and EE2 onto MIP but only in aqueous solution and never in WWTP effluent. Joseph et al. (2011) reported good removal efficiency up to $98 \%$ from sea water and brackish water with single-walled carbon nanotubes (CNTs). They recorded that removal efficiency is independent of $\mathrm{pH}$ and ionic strength. However, increasing concentrations of copresent organic matter decreases the removal of EE2 by $5-15 \%$.

Overall, the adsorption on activated carbon (PAC and GAC) is a very promising method to reduce trace organic micropollutants from WWTP effluents. Adsorption onto activated carbon is one of the two main technologies that have been identified in Switzerland and Germany with a potential for large-scale application concerning efficiency, energy requirements, and costs (Barjenbruch et al. 2014; Stamm et al. 2015). However, the increased amount of sludge (or loaded activated carbon) for disposal and the high operating costs must not be disregarded.

\section{Coagulation-flocculation}

In general, the coagulation-flocculation process is applied in WWTP to remove particulate matter. For the elimination of micropollutants, it is inefficient (Matamoros and Salvadó 2013). DCF was removed at a rate of $21.6 \%$ when using $\mathrm{FeCl}_{3} / \mathrm{Al}_{2}\left(\mathrm{SO}_{4}\right)_{3}$ as coagulant in hospital wastewater (Suarez et al. 2009). Dissolved humic acids could enhance its elimination (Vieno et al. 2006). The efficiency of coagulation- 
Table 7 Advanced technologies

\begin{tabular}{|c|c|c|c|}
\hline Sorbent & Amount of sorbent & Removal details & Reference \\
\hline \multicolumn{4}{|l|}{ Diclofenac } \\
\hline $\mathrm{AC}$ & $30 \mathrm{mg} \mathrm{L}^{-1}$ & $\begin{array}{l}\text { Activated carbon, P110 Hydraffin, (ultrapure water), tubular glass reactor } \\
\text { (300 mm long and } 50 \mathrm{~mm}, 93 \% \text { after } 20 \mathrm{~min}\end{array}$ & Beltrán et al. (2009) \\
\hline PAC & $50 \mathrm{mg} \mathrm{L}^{-1}$ & $\begin{array}{l}\text { Pilot scale, natural water with organic matter spiked with } 0.1 \mu \mathrm{g} \mathrm{L}{ }^{-1} \text {, } \\
\text { contact time } 4 \mathrm{~h}, 38-46 \%\end{array}$ & Snyder et al. (2007) \\
\hline PAC & $10-20 \mathrm{mg} \mathrm{L}^{-1}$ & $300 \mathrm{mg} \mathrm{L}^{-1} \mathrm{DCF}$, surface water, $2 \mathrm{~h} ; 76.7 \%$ & Dai et al. (2011) \\
\hline PAC & $23 \mathrm{mg} \mathrm{L}^{-1} \mathrm{PAC}$ & $8,23,43 \mathrm{mg} \mathrm{L}^{-1}$ in MBR effluent, hospital wastewater, $96,98,99 \%$ & Kovalova et al. (2012) \\
\hline $\mathrm{PAC} / \mathrm{UF}$ & $10-20 \mathrm{mg} \mathrm{L}^{-1}$ & $1.13 \mu \mathrm{g} \mathrm{L}^{-1} \pm 0.39$ WWTP effluent, $10-20 \mathrm{mg} \mathrm{L}^{-1}$ PAC, $69 \%$ & Margot et al. (2013) \\
\hline PAC & $5-10 \mathrm{mg} \mathrm{L}^{-1}$ & WWTP effluent; HRT 25-30 min, pilot scale, up to $98 \%$ & Mailler et al. (2014) \\
\hline GAC & Packed & Full scale; $>98 \%$ & Grover et al. (2011) \\
\hline GAC & Packed & Full scale (empty bed), 15 min contact & Yang et al. (2011) \\
\hline GAC/activated sludge & $0.5 \mathrm{~g} \mathrm{~L}^{-1}$ & Addition of GAC to bioreactor, $93 \%$ & Serrano et al. (2010) \\
\hline PAC/MBR & $1 \mathrm{~g} \mathrm{~L}^{-1}$ & Addition of PAC to bioreactor, $93 \%$ & Serrano et al. (2011) \\
\hline MIP & $10 \mathrm{mg} \mathrm{L}^{-1}$ & $300 \mathrm{mg} \mathrm{L}^{-1}$ DCF in surface water, MIP $97.6 \%$ & Dai et al. (2011) \\
\hline \multicolumn{4}{|l|}{ E2 } \\
\hline GAC & Packed & $\begin{array}{l}\text { Max. adsorption constant: } K_{\mathrm{d}} 12,200 \mathrm{~mL} \mathrm{~g}^{-1} \text { with } 24.8 \mu \mathrm{g} \mathrm{L}^{-1} \mathrm{E} 2 \\
\text { in water; } K_{\mathrm{d}} 7988 \mathrm{~mL} \mathrm{~g}^{-1} \text { with } 24.8 \mu \mathrm{g} \mathrm{L}^{-1} \mathrm{E} 2 \text { in WWTP effluent }\end{array}$ & Zhang and Zhou (2005) \\
\hline $\mathrm{AC}$ & $0.03-1.5 \mathrm{mg} \mathrm{L}^{-1}$ & $\begin{array}{l}\text { Various pore size distributions; max. adsorption capacity: } 67.6 \mathrm{mg} \mathrm{g}^{-1} \\
\text { at } 1 \mu \mathrm{g} \mathrm{L}^{-1} \text { in pure water }\end{array}$ & Fukuhara et al. (2006) \\
\hline GAC & Packed & Full scale; $100 \%$ & Grover et al. (2011) \\
\hline GAC, PAC & Packed, $5 \mathrm{mg} \mathrm{L}^{-1}$ & Full scale; $>90 \%$ for both materials & Snyder et al. (2007) \\
\hline MIP & & $25 \%$ & Meng et al. (2005) \\
\hline MIP & Packed & $95 \%$ from $2 \mu \mathrm{g} \mathrm{L}^{-1}$ in deionized water & Le Noir et al. (2007) \\
\hline MIP & $0.5-20 \mathrm{~g} \mathrm{~L}^{-1}$ & Dest water, $0.1-1 \mathrm{mg} \mathrm{L}^{-1} \mathrm{E} 2,97 \%, 15 \mathrm{mg} / \mathrm{g}$ & Lai et al. (2010) \\
\hline MIP & $0.25 \mathrm{~g} \mathrm{~L}^{-1}$ & $90 \%$ after 2 min incubation, $96 \%$ after long equilibrium & DeMaleki et al. (2010) \\
\hline \multicolumn{4}{|l|}{ EE2 } \\
\hline $\mathrm{AC}$ & Packed & $\begin{array}{l}\text { Highest adsorption at neutral conditions ( } 95 \%), 50 \mu \mathrm{g} \mathrm{L} \\
\text { EE2 solution (dest water) }\end{array}$ & Kumar and Mohan (2011) \\
\hline GAC & Packed & Full scale; $100 \%$ & Grover et al. (2011) \\
\hline Single-walled CNT & & $95-98 \%$, in sea water and brackish water & Joseph et al. (2011) \\
\hline Multiwalled CNT & & $25,50,75 \mu \mathrm{g} \mathrm{L}^{-1}$ aqueous solution; sorption capacity: $5.6 \mu \mathrm{g} \mathrm{g}^{-1}$ & Kumar and Mohan (2012) \\
\hline
\end{tabular}

$A C$ activated carbon, $P A C$ powdered activated carbon, $U F$ ultrafiltration, $G A C$ granular activated carbon, $M I P$ molecularly imprinted polymer, $C N T$ carbon nanotubes

flocculation can be influenced by different operating conditions such as $\mathrm{pH}$, temperature, alkalinity, presence of divalent cations, and concentration of destabilizing anions (Alexander et al. 2012).

\section{Physicochemical processes}

\section{Photolysis}

Irradiation with ultraviolet light (UV) is widely used in WWTPs for effluent disinfection prior to discharge into surface water. UV treatment is also known to transform some micropollutants through light absorption on photoactive groups, e.g., photoactive phenolics (Coleman et al. 2004). Two types of photocatalysis are known: (a) direct photolysis via direct absorption of light (Rosenfeldt and Linden 2004a, b) and (b) indirect photolysis, when photosensitizers (dissolved organic matter) adsorb the light and generate reactive oxygenated radicals performing the degradation of the target substance (Caupos et al. 2011). Numerous studies describe degradation of DCF, E2, and EE2 in deionized water but also in WWTP effluents up to $100 \%$ due to their high absorption values (Caupos et al. 2011; Rosenfeldt and Linden 2004a, b; Chowdhury et al. 2010; Silva et al. 2012; De la Cruz et al. 2012).

Kolarova et al. (2013) reported that the removal of DCF in $\mathrm{UV}_{254 \mathrm{~nm}}$ increases with increasing UV dose. While DCF was eliminated only $47 \%$ at $800 \mathrm{~J} \mathrm{~m}^{-2}$, over $98 \%$ removal was observed at $7200 \mathrm{~J} \mathrm{~m}^{-2}$.

Phototransformation has been identified as the important elimination process of DCF in the open environment (Pal et al. 2010). Although the turbidity of wastewater blocks some sunlight, water in the top layers (e.g., in clarifiers) will be well exposed to sunlight irradiation, especially in summer. 
Therefore, DCF phototransformation will occur in bright sunlight with half-life of less than $1 \mathrm{~h}$. Natural sunlight has also been shown to degrade EE2 (Pal et al. 2010).

\section{Radiation}

Ionizing radiation such as e-beam accelerators ( $\beta$-rays) and gamma irradiation ( $\gamma$-rays, $\left.{ }^{60} \mathrm{Co}\right)$, originally intended for disinfection, is under research for micropollutant degradation. Table 8 lists the facilities in Europe performing wastewater treatment by ionizing radiation.

The basic differences between these two sources are the dose rate and penetration. Gamma rays are highly penetrating, enabling the processing of bulk material. Ionizing radiation leads to $\mathrm{OH}$ radical formation in water dependent on dose, rate, and irradiation time (Borrely et al. 1998; Pikaev 2000; Getoff 2002). When wastewater is irradiated, organic molecules are oxidized. Irradiation excites water electronically and some ions, excited molecules, and free radicals are formed. In the presence of oxygen in water, $\mathrm{H}^{-}$-atoms and $\mathrm{e}^{-}$aq (solvated electrons) are converted into oxidizing species: Perhydroxyl radicals $\left(\mathrm{HO}_{2}\right)$ and anions $\left(\mathrm{O}_{2}{ }^{-}\right),\left(\mathrm{HO}_{2}\right)$ and $\left(\mathrm{O}_{2}{ }^{-}\right)$together with $\mathrm{OH}$-radicals initiate degradation of pollutants.

The gamma irradiation $\left({ }^{60} \mathrm{Co}\right)$ dose required for the elimination of estrogen activity below $1 \mathrm{ng} \mathrm{\textrm {L } ^ { - 1 }}$ has been found to be about $0.2 \mathrm{kGy}$ (Kimura et al. 2007a). Complete decomposition of DCF $\left(50 \mathrm{mg} \mathrm{L}^{-1}\right)$ in aqueous solutions requires $4.0 \mathrm{kGy}\left({ }^{60} \mathrm{Co}\right)$; however, saturation with $\mathrm{N}_{2} \mathrm{O}$ decreases the dose to $1.0 \mathrm{kGy}$ (Trojanowicz et al. 2012). The sterilization dose for DCF sodium salt, as a pharmaceutical raw material, has been found to be 12.4 kGy $\left({ }^{60} \mathrm{Co}\right)$ (Ozer et al. 2013). Homlok et al. 2011 described complete removal of DCF with $1.0 \mathrm{kGy}$. When cost is an issue, it is difficult to give a precise price for irradiation systems in advance because of the many factors involved: the kind and amount of pollutants in water, their properties (chemical, biological, etc.), dose-rate to be used, presence of ozone, combined methods of radiation, and conventional techniques. In general, costs decrease with increase of treatment capacity, and it is possible to say that $\gamma$-irradiation costs about four times more than ebeam irradiation because of the high cost of ${ }^{60} \mathrm{Co}$ source and the facility (Borrely et al. 1998).

\section{Ultrasonic treatment}

Ultrasonic treatment is also described as a method to degrade organic micropollutants. Ultrasonic treatment creates three zones of reaction solution: cavitation bubbles, supercritical interface, and bulk solution (Méndez-Arriaga et al. 2008; Naddeo et al. 2010). Méndez-Arriaga et al. (2008) and Chiha et al. (2010) reported that hydrophilic and nonvolatile compounds were mainly degraded in the bulk solution, whereas hydrophobic, nonpolar, and/or volatile compounds react in all three zones. DCF, EE2, and E2 are mainly attacked in bulk solution (Naddeo et al. 2009, 2010; Güyer and Ince 2011). It was found that DCF conversion is enhanced at increased applied power densities, acidic conditions, and in the presence of dissolved air (formation of hydroxyl radicals during ultrasonic treatment). They also reported that biodegradability increased after ultrasonic treatment (Naddeo et al. 2010; Güyer and Ince 2011).

\section{Oxidation with single strong oxidation agent}

Treatment of WWTP effluents with ozone $\left(\mathrm{O}_{3}\right)$ as oxidizer is one of the most studied chemical treatment technologies in Europe. Ozone oxidizes micropollutants directly or indirectly via HO radical formation (Gerrity et al. 2011). One of the first studies to remove DCF from wastewater was by Ternes et al. (2003). The authors employed ozone concentrations of 5.0 to $15.0 \mathrm{mg} \mathrm{L}^{-1}$ to investigate the removal efficiency in WWTP effluents which was $>96 \%$. Magdeburg et al. (2014) described an oxidation efficiency of $>90 \%$ for nine different micropollutants including DCF by ozonation of secondary effluent of WWTP using an ozone dose of $0.7 \mathrm{~g} \mathrm{~g}^{-1}$ DOC. These removal efficiencies are in the same range as reported by Hollender et al. (2009), Ternes et al. (2003), and Antoniou et al. (2013). Huber et al. (2005a) investigated the removal of estrogen activity by ozone at three different $\mathrm{pH}$ values $(3,7$, and 11). Estrogenic activity had disappeared at $\mathrm{pH} 3$, but residual activity remained after oxidation at $\mathrm{pH} 7$ and 11, probably due to by-product formation. Suspended sludge particles could lead to higher ozone consumption, which might reduce the efficiency of ozone for DCF, E2, and EE2 (HernándezLeal et al. 2011). Recently, Antoniou et al. (2013) investigated the required ozone doses for removing pharmaceuticals in wastewater effluents. They normalized the specific ozone

Table 8 Major facilities for wastewater treatment by ionizing radiation (Borrely et al. 1998)

\begin{tabular}{llllll}
\hline Country & Radiation source & Energy $(\mathrm{MeV})$ & Power $(\mathrm{kW}) /$ activity $(\mathrm{kCi})$ & Purpose & Dose $(\mathrm{kGy})$ \\
\hline Austria & EBA & 0.5 & 12.5 & TCE, PCE removal & $0.2-2.0$ \\
Germany & ${ }^{60} \mathrm{Co}$ & 1.25 & 135 & Disinfection of sludge & $2.0-3.0$ \\
\hline
\end{tabular}

$E B A$ electron beam accelerator, $T C E$ trichloroethylene, $P C E$ perchloroethylene 
dose to the dissolved organic carbon (DOC) of the effluent, which resulted in an applied ozone dose $\left(\mathrm{DDO}_{3} / \mathrm{DOC}\right)$ ratio of 0.67 for DCF.

Because ozonation has been considered a second promising technology in Europe during the last years, some of WWTPs in Switzerland and Germany have been upgraded with ozone oxidation or/and activated carbon adsorption (Barjenbruch et al. 2014; Stamm et al. 2015). While in an adsorptive process using PAC or GAC organic micropollutants are removed, oxidation processes like ozonation do not result in complete mineralization of micropollutants but in the formation of predominantly unknown transformation products (TP) with unknown toxicity. Additionally, inorganic by-product from oxidation will be formed (Joss et al. 2008; Stadler et al. 2012).

In general, the TP have low concentrations as well as insignificant estrogenic and antimicrobial activities compared to the parent compound (Hollender et al. 2009; Reungoat et al. 2011). To further reduce TP, biological post-filtration over activated carbon or sand can be considered (Luo et al. 2014).

Huber et al. (2005b) investigated the potential of chlorine dioxide $\left(\mathrm{ClO}_{2}\right)$ for the oxidation of DCF and EE2 during water treatment (drinking water, groundwater, and lake water; not wastewater). $\mathrm{ClO}_{2}$ is a stable free radical that reacts with micropollutants through a one-electron transfer and is a highly selective oxidant with respect to specific functional groups like phenolic groups (Huber et al. 2005b). DCF $\left(1 \mu \mathrm{g} \mathrm{L}{ }^{-1}\right)$ was readily oxidized with $\mathrm{ClO}_{2}$ in $30 \mathrm{~min}$ with a dose of 0.95 $11.5 \mathrm{mg} \mathrm{L}^{-1} \mathrm{ClO}_{2}$ but in lake water only after $60 \mathrm{~min}$. EE2 $\left(11 \mu \mathrm{g} \mathrm{L}^{-1}\right)$ reacted very fast in less than $5 \mathrm{~min}$ with $0.1 \mathrm{mg} \mathrm{L}^{-1} \mathrm{ClO}_{2}$ in groundwater (Huber et al. 2005b). There are no studies available for WWTP effluents.

When the degradation of EE2 and DCF was studied under $\mathrm{MnO}_{2}$ or biogenic produced manganese oxides (BioMnOx) in a synthetic wastewater (Forrez et al. 2009, 2010), removal of up to $80 \%$ could be verified. At neutral $\mathrm{pH}$, the diclofenac oxidation with BioMnOx was 10-fold faster than with chemically produced $\mathrm{MnO}_{2}$. The main advantage of BioMnOx over chemical $\mathrm{MnO}_{2}$ is the ability of bacteria to reoxidize the formed $\mathrm{Mn}^{2+}$, which inhibits the oxidation of DCF. Diclofenac oxidation was proportional to the amount of BioMnOx dosed, and the pseudo first-order rate constant $k$ was 6-fold higher when $\mathrm{pH}$ was decreased from 6.8 to 6.2. These results combined with previous studies suggest the potential of BioMnOx for WWTP effluent polishing, but the technique is not yet used in technical scale.

\section{Advanced oxidation processes}

Advanced oxidation processes (AOPs) are very effective in the oxidation of numerous organic and inorganic pollutants. AOPs are based on the generation of free radicals, mainly the
$\mathrm{HO}^{\circ}$ radical, with high oxidizing power, which can successfully attack most organic molecules with elevated reaction constants from $10^{6}$ to $10^{9} \mathrm{M}^{-1} \mathrm{~s}^{-1}$ (Von Sonntag 2008; Huber et al. 2003; Rivera-Utrilla et al. 2013). This makes AOPs superior to treat organic molecules with high chemical stability and/or low biodegradability (Oller et al. 2011). Due to their electrophilic nature, $\mathrm{HO}^{\circ}$ radicals oxidize almost all electron-rich organic substances, eventually converting them to carbon dioxide and water. Most AOPs use a combination of two different oxidants (e.g., $\mathrm{O}_{3} / \mathrm{H}_{2} \mathrm{O}_{2}$ ), oxidant and irradiation (e.g., $\mathrm{H}_{2} \mathrm{O}_{2} / \mathrm{UV}$ ), oxidant and catalyst (e.g., $\mathrm{H}_{2} \mathrm{O}_{2} / \mathrm{Fe}^{2+/ 3+}$ (Fenton)), oxidant and photocatalyst (e.g., $\mathrm{H}_{2} \mathrm{O}_{2} / \mathrm{UV} / \mathrm{Fe}^{2+/ 3+}$ (photo-Fenton), or oxidant and ultrasonic (e.g., $\mathrm{H}_{2} \mathrm{O}_{2} /$ ultrasonic) (Von Gunten 2003; De la Cruz et al. 2012). Many of these advanced systems have been evaluated in laboratory batch tests and have yet to be applied on technical scale; thus, there is a lack of good quality data on the mechanisms involved, the influence of operational variables, the reaction kinetics, and reactor design issues.

Gerrity et al. (2011) reported high removal efficiency for DCF of $>99 \%$ and of $\mathrm{E} 2$ of $>83 \%$ in a pilot-scale treatment plant of WWTP effluent with $\mathrm{O}_{3} / \mathrm{H}_{2} \mathrm{O}_{2}$. Recently, RiveraUtrilla et al. (2013) and Silva et al. (2012) exhaustively reviewed the literature on the removal of pharmaceuticals from water, summarizing also the performances of different water treatment systems including advanced technologies. In the case of DCF, EE2, and E2, some promising technologies have been identified and summarized in Table 9 .

In recent years, the electrochemical based AOPs (EAOPs) have gained more attention due to several advantages over normal AOPs (Martínez-Huitle and Ferro 2006; Sirés et al. 2014; Sirés and Brillas 2012). The EAOPs are clean technologies that do not use any chemicals during the process. Besides, the operation under mild (room temperature and ambient pressure) and versatile (applicable to CODs of 0.1 to $100 \mathrm{~g} \mathrm{~L}^{-1}$ ) conditions, the high energy efficiency, and the easy handling are - among others - advantages that distinguish the application of EAOPs from classical methods (Sirés et al. 2014). The EAOPs can be classified into two groups: (1) anodic oxidation (AO), where, at the anode surface, in situ $\mathrm{OH}$ radical is generated (e.g., boron-doped diamond electrodes (BDD); and (2) electro-Fenton (EF), via in situ electrocatalytically generated Fenton's reagent, including different coupling with other photo-, sono-, or physio-chemical treatment methods (Oturan and Aaron 2014). The anode material is a crucial element in an EAOP. Originally, the AO process was conducted with high $\mathrm{O}_{2}$ evolution overpotential anodes (Brillas and Martinez-Huitle 2011), such as Pt, graphite, $\mathrm{PbO}_{2}$, doped $\mathrm{SnO}_{2}, \mathrm{IrO}_{2}$, or dimensionally stable (DSA) anodes. An essential feature of the anode material is to inhibit the generation of oxygen molecules and to impose the formation of significant amounts of oxidizing agent such as hydroxyl radicals (Comninellis et al. 2008). The previously reported 


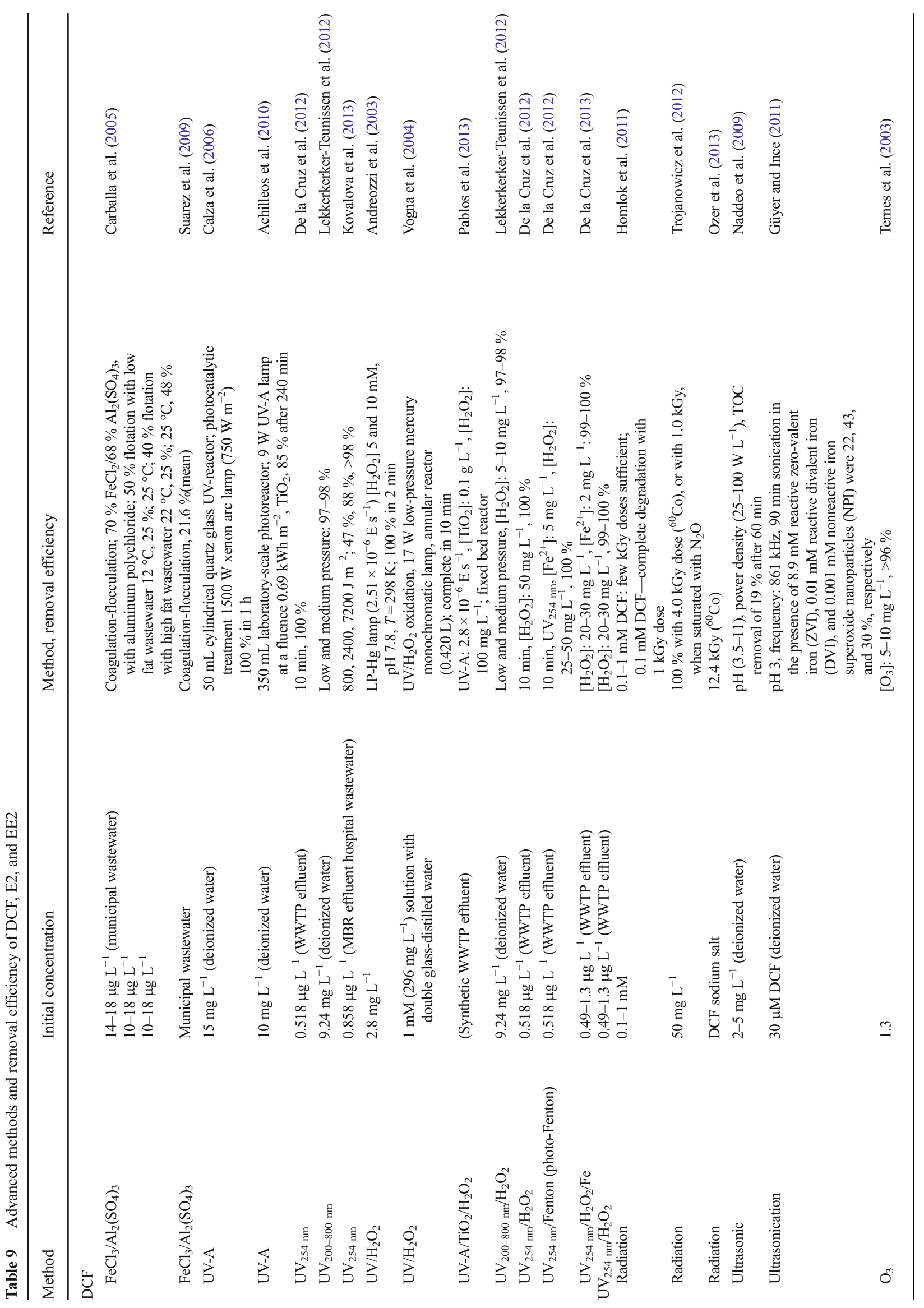




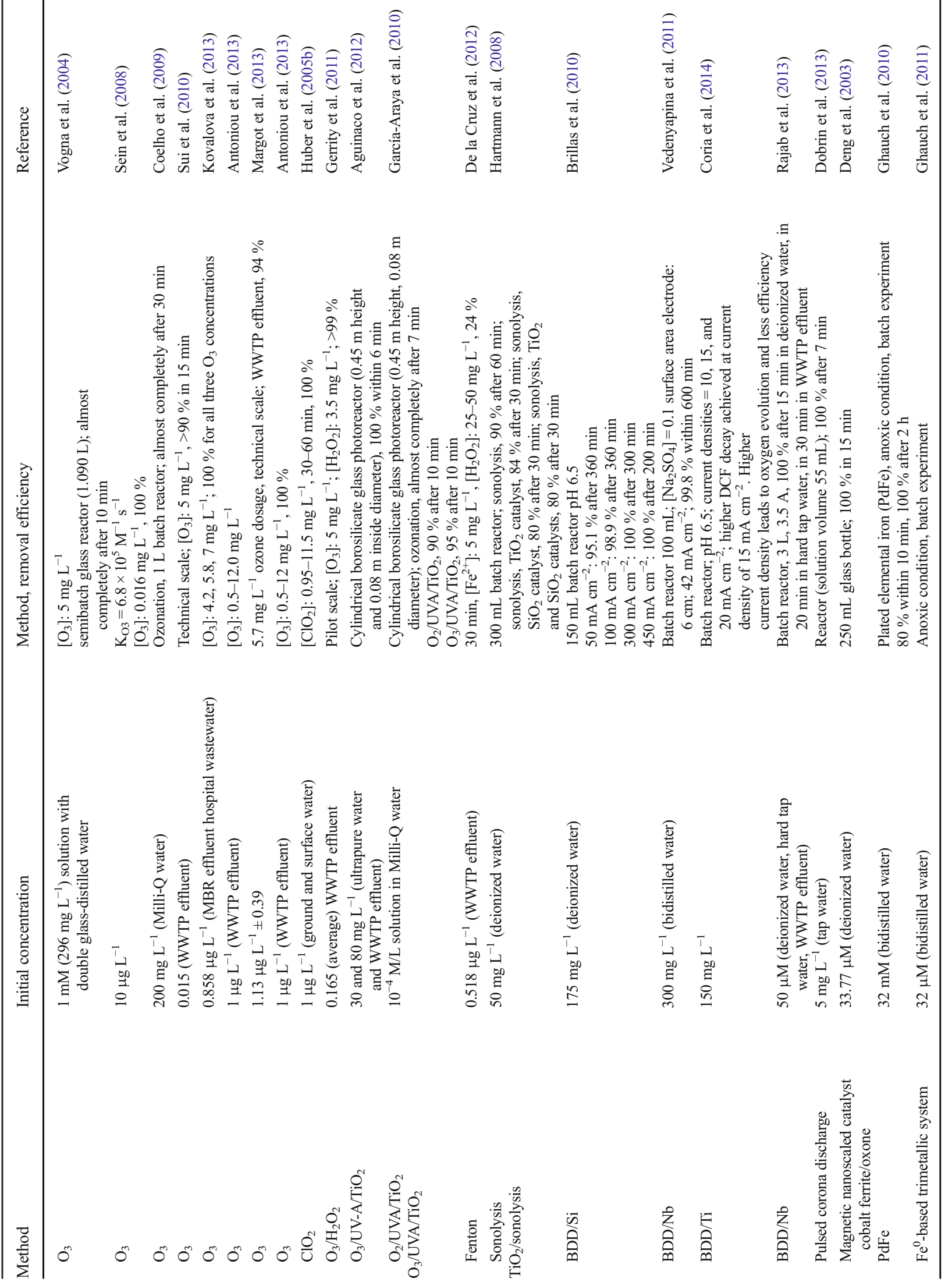




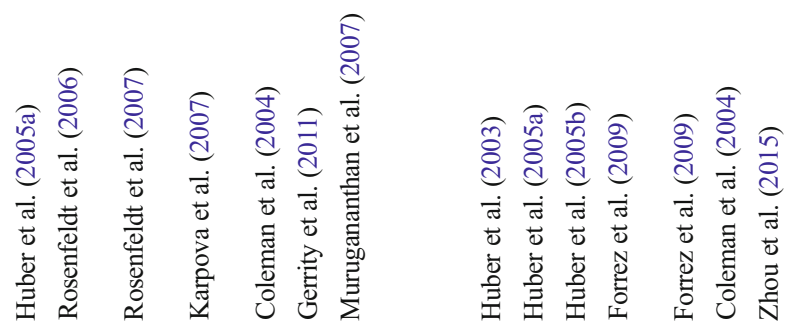

ニニニ

还密

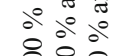

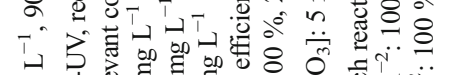

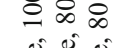

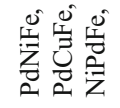

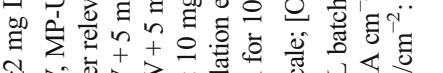

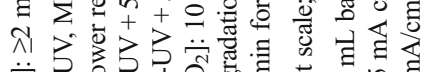

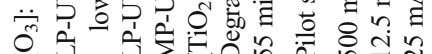
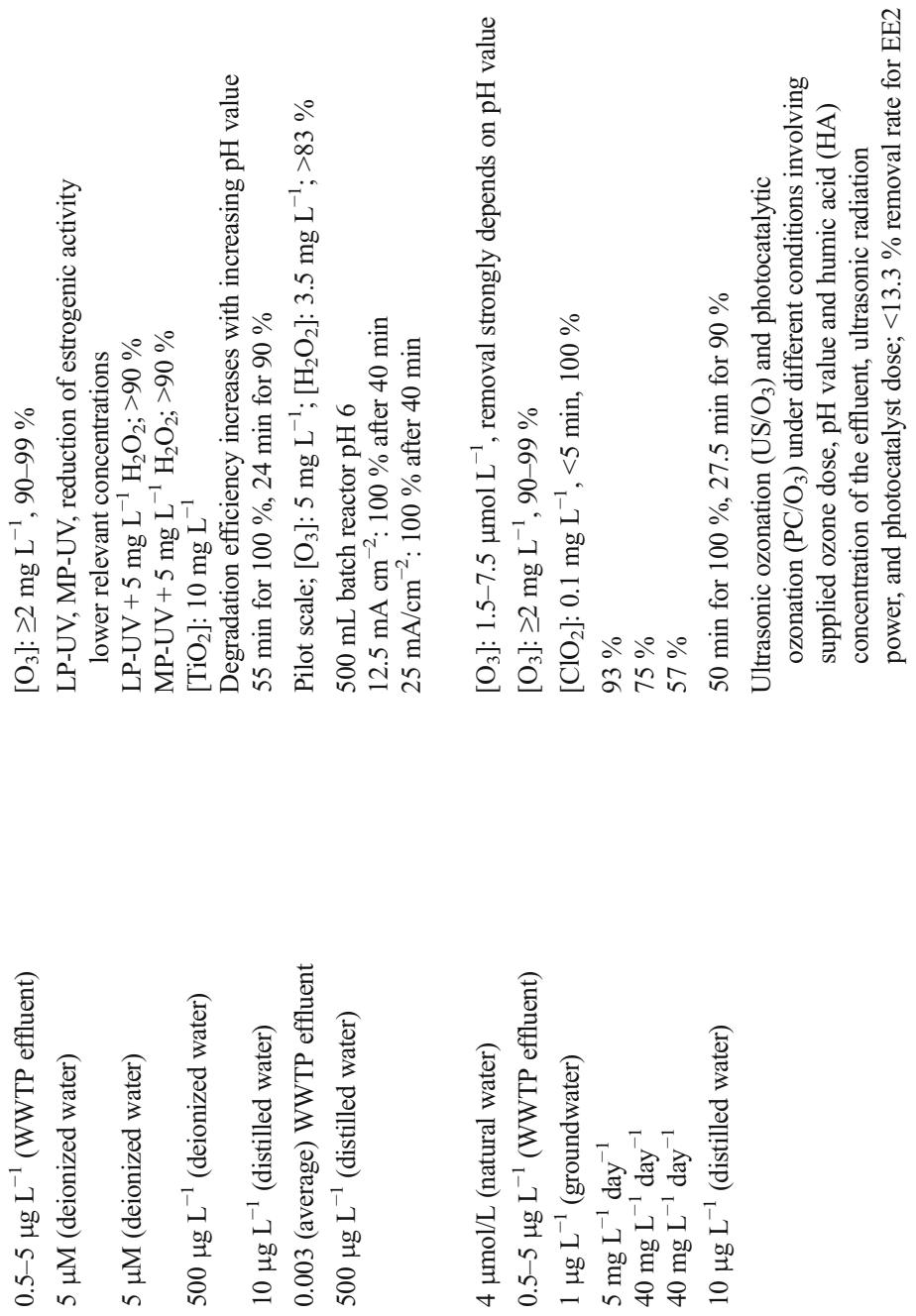

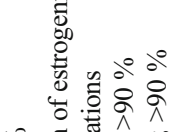

वे

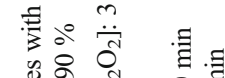

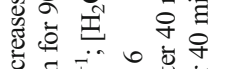

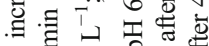
政 $T$ के क

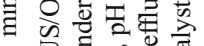

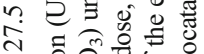
ᄋी

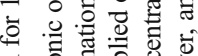

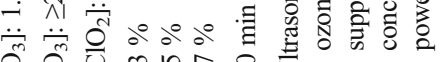
- 0 arin

.


electrode materials are not stable against the reactive species formed on their surfaces and erosion of the material would be possible (Barrera-Díaz et al. 2014). The boron-doped diamond (BDD) electrode, however, shows an outstanding specificity for electrochemical oxidation processes promoting it as a very promising anode material (Fryda et al. 2003; Kraft et al. 2003; Tröster et al. 2004; Martínez-Huitle and Quiroz Alfaro 2008). Depending on the source of the water, the degradation progress may be quite heterogeneous, due to competitive reactions with organic and inorganic matter at high concentrations in hard water and WWTP effluents (Wert et al. 2011; Rajab et al. 2013). AOPs and EAOPs have been tested mainly in lab scale and are far from technical application, also because of byproduct formation and costs.

Heterogeneous photocatalytic oxidation is a method relying on the capability of photocatalysts like titanium dioxide $\left(\mathrm{TiO}_{2}\right)$, zinc oxide $(\mathrm{ZnO})$, zinc sulfide $(\mathrm{ZnS})$, ferric oxide $\left(\mathrm{Fe}_{2} \mathrm{O}_{3}\right)$, silicon (si), and tin oxide $\left(\mathrm{SnO}_{2}\right)$ to act as sensitizers for light-induced redox processes (Silva et al. 2012). $\mathrm{TiO}_{2}$ is the most widely cited photocatalyst due to its considerable activity, high stability, nonenvironmental impact, and low cost (Augugliaro et al. 2012; Silva et al. 2012). The heterogeneous photocatalysis process using $\mathrm{TiO}_{2}$ was applied successfully for the removal of DCF, E2, and EE2 with high removal efficiencies in aqueous solutions including WWTP effluents. Selected studies are listed in Table 9. Coleman et al. (2004) found a selectivity for estrogens EE2 $>$ E2. The removal efficiency of E2 and EE2 increases with increasing $\mathrm{pH}$ value (Karpova et al. 2007).

None of the AOPs mentioned above will result in a complete mineralization of organic micropollutants. Transformation products are formed which could be biodegradable but also toxic, bound, or mobile, which makes a biological posttreatment to degrade these TP indispensable (Christensen et al. 2009).

\section{Phytoremediation}

\section{$D C F$}

Recent reviews have indicated that besides longer SRT and HRT, the implementation of wetland plants might improve the performance of older WWTPs in small settlements. Recommendations have been made to add lagunar phytoremediation modules to improve the removal of PPCPs even more effectively (Schröder et al. 2007). In such systems, the uptake and removal of DCF and estrogens relies on the biology of green plants and their accompanying rhizospheric microbial communities, in analogy to mammalian detoxification systems.

In humans, many drugs undergo a cascade of different reactions. An initial activation reaction is frequently followed by conjugation with smaller biomolecules like glucuronic acid or sulfuric acid. These modifications of the parent drug increase its solubility and the potential for excretion of active metabolites. The very same mechanisms exist in plants (Schröder and Collins 2002), and it has been demonstrated that they are active against a broad spectrum of xenobiotic compounds. In mechanistic laboratory and greenhouse studies with different plant species (Armoracia rusticana, Brassica juncea, Hordeum vulgare, Lupinus luteolus, Typha latifolia, Phragmites australis), the uptake and subsequent detoxification of DCF has recently been demonstrated (Kotyza et al. 2010; Huber et al. 2012; Bartha et al. 2014). Since DCF is a weak acid, its uptake in the plant with the transpiration stream is not inhibited, and significant concentrations accumulate in both roots and shoots of investigated species. Interestingly, the pharmaceutical is attacked by enzymes very similar to mammalian ones. After activation by $\mathrm{P} 450$ or peroxidase enzymes, the hydroxylated primary metabolites were conjugated either with glucose, or glutathione (Fig. 2), rendering the products more water soluble and nontoxic.

\section{Estradiols}

Phytoremediation of ECDs has been investigated in different studies. The removal of $17 \beta$-estradiol and $17 \alpha$ ethinylestradiol from contaminated waters by macrophytes was discussed by Trueman and Erber (2013). The authors studied the uptake of two estrogenic compounds as well as Bisphenol A into the tissues of two Potamogeton species. Whereas the amounts of the estradiol compounds in both

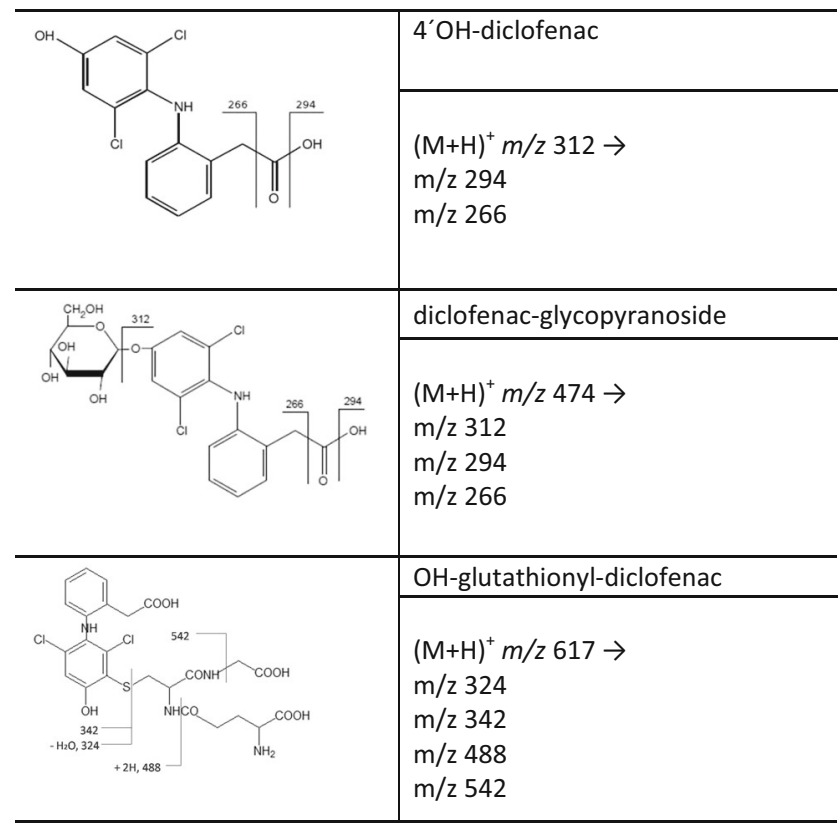

Fig. 2 Chemical structures of diclofenac metabolites identified in plants and the characteristic mass transitions obtained in positive ionization mode by LC-MS/MS analysis 
species were rather low $\left(15.7 \mathrm{ng} \mathrm{L}^{-1}\right)$ compared to the concentration in the water, the plants took up a considerable amount of Bisphenol A ( $\left.8.3 \mu \mathrm{g} \mathrm{g}^{-1} \mathrm{DW}\right)$.

The use of vertical flow wetlands is a common technique in phytoremediation. Planted with common reed (Phragmites australis) these systems have been tested for the removal of endocrine disruptors from wastewaters (Song et al. 2009). The authors reported a maximal removal efficiency of 67.8 $\pm 28.0 \%, 84.0 \pm 15.4 \%$ and $75.3 \pm 17.6 \%$ for E1, E2 and EE2, respectively. In a comparison of different wetland depths, they found the shallowest $(7.5 \mathrm{~cm})$ to be the most efficient one to remove EDCs from the water body.

Apart from macrophytes, Duckweed (Lemna species) and a mixture of algae and cyanobacteria were studied for their capacity to remove ECDs from synthetic wastewater under different conditions in batch experiments. In the presence of duckweed and algae, effective removal of the estrogens E1, $\mathrm{E} 2$, and EE2 from waters was observed, even at nanogram per liter concentrations (Shi et al. 2010). The accelerated removal of estrogens is probably due to its absorption on the duckweed or algae and subsequent degradation by microorganisms adhering to the plants. However, plant metabolism was not excluded, and duckweed showed a slightly higher efficiency to remove estrogens than algae.

Generally, for the use of plants in any remediation scenario, the selection of the most suitable species to do the job is crucial (Schröder 2007). This includes knowledge of the plants' metabolic capacity, their ability to grow under given environmental conditions, and favorable milieu (e.g., oxygen, root surface, chemical milieu) for plant-associated microorganisms which may contribute to degradation and removal of the pollutants in manifold ways. When using macrophyte species, it remains important to remove all plants after remediation to avoid the release of sequestered nutrients and pollutants back into the system during decomposition. In many cases, especially for small settlements, phytoremediation, when properly performed, may be an appropriate and costeffective way to remove considerable amounts of pollutants from aquatic ecosystems and WWTPs.

\section{Ecotoxicology and risk assessment}

While compilations on the occurrence and fate of pharmaceutically active compounds and their metabolites in sewage and potable water are increasingly available and point to the danger of their widespread distribution (Sweetman 2002; Petrović et al. 2014; Škrbić et al. 2014), the environmental effects of their presence alone and in mixtures have so far not been properly addressed (Halling-Sorensen et al. 1998; Daughton 2001; Ternes 2001; Arnold et al. 2013; Manickum and John 2014; Vieno and Sillanpää 2014; Shore et al. 2014; Gabet-Giraud et al. 2014). In this section, the main ecotoxicological issues related to diclofenac and EE2 are summarized; for a wider discussion on the topic, the reader is referred to the accompanying paper on ecotoxicity of micropollutants (Papa et al., in preparation).

\section{Pure compound approach}

The objective of an environmental risk assessment (ERA) is to prove, beyond reasonable doubt, that the compounds are safe for all manmade and natural ecosystems which they may enter, such as WWTPs, rivers, and soil. A compound is judged as having little or no environmental risk if the predicted environmental concentration (PECs) - which is the concentration of the compound expected to be found in the environment-is lower than the predicted no effect concentration (PNEC) - that is, the concentration that causes no adverse effect to the environment. However, the compounds are rarely present alone in the environment; hence, the concentrations of compounds that are asserting similar adverse effects in the environment are usually added for the ERA (Fent et al. 2006). Moreover, since many compounds may be altered prior to or during treatment, and/or in the receiving organisms themselves, further potential metabolites (relevant for many pharmaceuticals) and transformation products should be included in the assessment.

The ERA is a tiered process that progresses from using screening-level tests and conservative assumptions to increasingly more realistic assumptions (EC 2003). The PNEC is typically obtained from the lowest effect concentration (LOEC) for the most sensitive species. However, ecotoxicity data are often limited or not available, especially for metabolites and transformation products. Hence, the traditional ERA, as described by the European Commission Technical Guidance Document (TGD), allows the use of assessment factors to account for the uncertainty in deriving PNEC values based on acute toxicity data and a limited number of species (EC 2003). For biologically active compounds such as pharmaceuticals, this approach may overlook sublethal and subtle subcellular effects that may occur in some species at much lower concentrations during chronic exposure (Fent et al. 2006).

Typical PNEC values for diclofenac and EE2 when derived from traditional ERA using acute toxicity data lies in the milligram per liter range, while chronic histopathological effects have been observed in rainbow trout after 28 days of exposure to $1-5 \mu \mathrm{g} \mathrm{L}^{-1}$ DCF (Schwaiger et al. 2004; Triebskorn et al. 2004). The fact that diclofenac also bioaccumulates is also of concern and should be addressed properly (Fent et al. 2006). Kallio et al. (2010) found that the total bioconcentration factors $\left(\mathrm{BCF}_{\text {total }}\right)$ for diclofenac and its metabolites in rainbow trout bile varied between individuals and was roughly estimated to range from 320 to 950 .

As for EE2, Caldwell et al. $(2008,2012)$ proposed a PNEC value of $0.1 \mathrm{ng} \mathrm{L}^{-1}$ in surface water. It was derived from a species sensitivity distribution using no observed effect 
concentrations (NOECs) for reproductive effects from 42 papers in 26 species and was determined as the median hazardous concentration at which $5 \%$ of the species tested were affected $(\mathrm{HC} 5,50)$.

\section{Whole-effects approach}

Another approach to the assessment of micropollutants would be to switch from a compounds-oriented to an effects-oriented one, in order to take into account (i) unknown/undetected compounds, like metabolites and parent compounds, and (ii) the mixture effects of substances, either synergistic or antagonistic. Therefore, comprehensive bioanalytical tools can directly measure the specific biological activity of groups of chemicals. This is just the case for EE2: indeed, when assessing its ecotoxicological effects, the main threat is represented by the induced estrogenic activity, i.e., a specific mode of toxic action directly related to all those molecules (then called endocrine-disrupting compounds, EDCs) that can mimic, block, or interfere with hormonal activities in living organisms. In regard to ERA for the receiving water bodies, the main adverse impact related to this kind of biological activity is represented by impaired reproductive performance in wildlife and especially in fish: levels of $0.1-0.4 \mathrm{ng} \mathrm{L}^{-1}$ were postulated by Jarošová et al. (2014) for safe concentrations of estrogenic equivalents (EEQs) for municipal WWTP effluents. The concept of estrogenic equivalents is used to group all the chemicals able to induce this specific mode of toxic action, and is measured via estrogenic activity assays (Leusch et al. 2010). They are based on the interaction between compounds and estrogenic receptors and can be performed with cells (E-SCREEN, ER-CALUX, MELN, and KBluc assays) and yeast (YES assay) (Leusch et al. 2010).

\section{Modeling of diclofenac and hormones}

In wastewater treatment plants, mathematical models are routinely used for plant design, optimization, and control. In general, the most commonly used models are derived from the activated sludge models (ASMs) that were developed to predict the degradation of organic carbon, nitrogen, and phosphorus (Henze et al. 2000). In recent years, ASMs have been extended to include the degradation of micropollutants, including pharmaceutical compounds such as diclofenac and estrogens such as E2 and EE2 (Lust et al. 2012; Plosz et al. 2012). These models have been developed to primarily include removal mechanisms associated with biotransformation and adsorption, since removal via volatilization/stripping has been found to be comparatively negligible for these compounds.

In the modeling of biotransformation processes, separate kinetic expressions are typically employed in order to describe both aerobic and anoxic degradation (Joss et al. 2004, 2006). Biotransformation, described by Joss et al. (2004, 2006) through pseudo first-order degradation kinetics, generally occurs at a higher rate aerobically than anoxically, due to the contribution of autotrophic bacteria (i.e., nitrifiers), which often display higher kinetics for pharmaceutical degradation than heterotrophic bacteria. Adsorption and desorption are typically estimated assuming an equilibrium between the dissolved and sorbed concentration of the respective pharmaceutical. This equilibrium is dependent on the suspended solids concentration. The sorption behavior for pharmaceuticals such as DCF and estrogens will routinely be estimated by their $K_{\mathrm{d}}$ (see "Conventional treatment systems and their shortcomings").

The ASM-X model developed by Plosz et al. (2012) for DCF (and other pharmaceuticals) incorporates expressions involving both the biotransformation of the micropollutant and its reformation into the parent compound. This is due to the fact that closely related DCF conjugates can also be found in influent wastewaters (typically generated as human metabolites), where the parent DCF molecule is then reliberated biologically through conjugate-cleavage in the activated sludge process. The biodegradation of DCF is predicted through both direct biodegradation as well as through cometabolic biodegradation via other soluble substrates present in the wastewater. While sorption and desorption of DCF to the sludge was predicted through its $K_{\mathrm{d}}$, Plosz et al. (2012) also employed a term to predict the fraction of DCF sequestered in sludge to account for the fact that the sorbed DCF detected in the activated sludge was substantially higher than that predicted by liquid-solid equilibrium.

Models describing the biodegradation of estrogens (estrone (E1), E2) and EE2 have also been developed (Monteith et al. 2008; Lust et al. 2012), which also predict both their biodegradation and adsorption/desorption to sludge through liquidsolid equilibrium $\left(K_{\mathrm{d}}\right)$ coefficients. With respect to biodegradation, since $\mathrm{E} 1$ is formed from $\mathrm{E} 2$ biodegradation, sequential degradation of E2 to E1 has been considered in these models as the major biochemical pathway. Formation of conjugated estrogens was also incorporated into the model of Lust et al. (2012).

Recently, the ASM-X model has also been incorporated into the benchmark simulation model (BSM) structure in order to facilitate its integration with plant-wide control strategy scenarios (Snip et al. 2014). This study also proposed a dynamic influent prediction tool to estimate the concentration of, e.g., DCF as a function of administration pattern, bioavailability, and residence time in the human body.

Now it will be necessary to include the transformation of these compounds in tertiary treatment processes, such as filtration, UV, and ozonation, eventually combined with phytoremediation, considering the fact that these processes have been typically found to contribute to a substantial portion 
of the removal of pharmaceutical compounds. Of course, kinetic approaches regarding the generation of TPs from DCF or estrogen biotransformation or oxidation processes must be included, particularly in view of the toxicity that such metabolites may exhibit, often higher than the parent compounds themselves, and that they may constitute the bulk chemical from reaching and persisting within the environment.

WWTP effluents, if properly treated, can be reclaimed and reused for determined restricted uses, contributing in this way to the reduction of water pollutants and the pressure over the worldwide water scarcity. It will be also up to the models to forecast limits of such technologies and develop action plans for optimized remediation techniques aiming at avoiding the release of these substances into the environment, to preserve the ecosystem but also protect biodiversity.

\section{Economics}

The level of pollutant removal from wastewater exponentially increases the associated costs. When the treatment involves micropollutants like the DCF and estrogens, there is also an additional cost due to the advanced technology required. Owen and Jobling (2012) reported that, in order to remove EE2 from wastewater to comply with the proposed legislation, GAC systems should be implemented in all conventional WWTPs. The investment cost of such a system for a town of 250,000 inhabitants would be around 8 million $€$, and its operating costs around $800,000 €$ per year. A similar finding was drawn by Jones et al. (2007), who concluded that the cost of utilizing drinking water technologies to treat wastewater will likely be really expensive. In particular, it was estimated that for medium- and large-sized WWTPs, the capital cost of sand filter and membranes exceeded the cost of the basic activated sludge WWTP by $2.63 £$ and 1.5 million $£$, respectively. Moreover, the potential operating costs of the extra treatment processes would be also significantly higher than standard treatment, since they would increase by around six times.

Since economies of scale apply to wastewater treatment facilities (Tsagarakis et al. 2003; Fraquelli and Giandrone 2003; Hernandez-Sancho et al. 2011), the cost for removing micropollutants from small installations will be extremely high. Advances in technology are promising in achieving high removal rates for micropollutants (see section "Advanced and alternative methods") but should be achieved with affordable tariffs for the residents. The main challenge is to quantify the benefits of micropollutant removal, which is difficult, since the level of damage to the environment and biodiversity has yet to be fully taken into account (Luo et al. 2014; Vieno and Sillanpää 2014; Pereira et al. 2015).

In such cases, nonmarket valuation can be applied so that a monetary value can be attributed to the benefits derived from the wastewater treatment (Menegaki et al. 2007; Genius et al.
2012). Since costs are transferred to the residents, any new investment for advanced treatment should be investigated for acceptance and willingness to pay for the capital and operation cost. This is essential since residents will be asked to pay for higher tariffs (Genius et al. 2005).

Literature is very scarce on nonmarket valuation of micropollutants. In a contingent valuation study, Kotchen et al. (2009) investigated the willingness to pay for a surcharge on prescriptions to support a pharmaceutical disposal program in southern California. Logar et al. (2014) report findings from a choice experiment, aimed at giving monetary value to benefits deriving from reducing environmental risks of specific micropollutants, including, among others, diclofenac. These benefits are then entered in a cost benefit analysis for the Swiss national plan to reduce micropollutants in treated wastewater effluents, resulting in a positive net present value of this policy.

In another context, Molinos-Senante et al. (2013a, b) quantified the environmental benefits of preventing the discharge of DCF and EE2 into water bodies using the distance function approach. They estimated the shadow prices of those compounds, which can be interpreted as the economic value of environmental benefits to avoid the discharge of contaminants into the environment. In particular, for nonsensitive areas, the shadow prices of the DCF and EE2 were quantified by 42.20 and $73.73 € \mathrm{~kg}^{-1}$, while for sensitive areas, they were 53.47 and $93.76 € \mathrm{~kg}^{-1}$, respectively. These figures represent the positive externalities of removing both pollutants from wastewater with the highest available standards. For example, the value of $42.20 € \mathrm{~kg}^{-1}$ means that for each kilogram of DCF that is removed from wastewater, the environmental benefit is quantified by 42.20 $€$. It should be noted, that to estimate the overall benefits from wastewater treatment, not only the value of the shadow prices in $€$ per kilogram should be considered, but the volume of each pollutant removed in kilogram per cubic meter as well.

\section{Concluding remarks}

Nearly half of the European countries are facing water stress issues today, both in terms of water scarcity and water quality deterioration, and it is estimated that 20-40\% of Europe's available water is being wasted (lack of water-saving technologies installed, too much unnecessary irrigation, etc.). In addition, priority and emerging organic pollutants and pathogens are continuously discharged into European rivers and streams, thereby compromising valuable ecosystem services and resulting in potentially adverse effects to aquatic organisms. This is due to the fact that our conventional WWTPs are neither specifically designed nor operated to remove residual concentrations of organic pollutants, causing the potential accumulation of such pollutants into receiving water bodies and 
limiting at the same time proper reuse of water. Although concentrations of DCF and EE2 in groundwater and surface waters are still generally low and an acute toxicological risk for consumers has not been identified so far, contamination is increasing, like for other emerging compounds.

Cleaning highly treated wastewater through an environmental buffer and stripping residual contaminants into the matrix by sorption and occult microbial processes to augment a drinking water supply is a recent practice, which is referred to as intentional indirect potable reuse, which can occur through recharge of unconfined or confined aquifers. It has been demonstrated by several projects that nonpotable and potable water reuse can represent a viable option to diversify local water resources while at the same time reducing the demand for conventional freshwater supplies. In consequence, the potential economic value of this particular water is decreased.

At this time, there are some novel potent remediation technologies available for conventionally treated wastewater applying, e.g., filtration, adsorption, or ozonation. Typically, they contribute to a substantial removal of pharmaceutical compounds such as DCF and EE2. But only adsorption onto activated carbon and ozonation are techniques which have reached marketable technology readiness levels in Europe at present. Further research needs to be directed into the optimization of such technologies or the transfer of promising technologies and combinations of processes from laboratory to technical scale. WWTP effluents, if properly treated, can be reclaimed and reused for determined restricted uses, contributing in this way to the reduction of water pollutants and the pressure over the worldwide water scarcity. Nevertheless, the use of inadequately treated wastewaters for irrigation will definitely raise public health concerns arising from the presence of microorganisms and contaminants of emerging concern.

This situation strongly calls for the development of optimized remediation techniques to generally limit the release of these substances in the environment. It is also evident that in order to protect resources for future generations, approaches have to be adopted, which sustainably protect ecosystems and biodiversity.

With the increasing need to alleviate the load of emerging contaminants, treatment facilities across Europe need upgrading to fulfill water standards and to keep the end users healthy. The lack of knowledge about the occurrence of many emerging organic pollutants in WWTP effluents as well as about the efficiency of treatment options must be overcome. Interdisciplinary initiatives like the COST Action ESSEM 1202 (Conceiving Wastewater Treatment in 2020Energetic, environmental and economic challenges; http:// www.water2020.eu) are a potent instrument to collect knowledge and feed it into discussion panels. From starting points like those, it will be urgently required to develop overall evaluation schemes for wastewater management, including its energetic, environmental, and economic challenges, to provide national and EU authorities with useful and reliable decision support tools for future investments and implementations. Among these tools, validated sampling and analytical techniques, (eco-) toxicological assessment, and sound economical background data have to be made available. Existing WWTPs need to be upgraded by most advanced modules, enhancing degradation and optimizing overall retention times.

And last but not least, for groundwater, one of our most valuable resources, in addition to the requirements of good status, any significant and sustained upward trend in the concentration of any pollutant should be identified and reversed as early as possible.

Acknowledgments This opinion paper has been compiled by members of COST Action ESSEM1202 (www.water2020.eu) on the basis of fruitful discussions in a task force focusing on emerging contaminants. The authors acknowledge the financial support by COST (www.cost.eu) for their meetings.

Open Access This article is distributed under the terms of the Creative Commons Attribution 4.0 International License (http:// creativecommons.org/licenses/by/4.0/), which permits unrestricted use, distribution, and reproduction in any medium, provided you give appropriate credit to the original author(s) and the source, provide a link to the Creative Commons license, and indicate if changes were made.

\section{References}

Abegglen C, Escher B, Hollender K, Ort C, Peter A, Siegrist H, Von G, Zimmermann S (2009) Ozonierung von gereinigtem Abwasser. Schlussbericht Pilotversuch Regensdorf; Studie der Eawag im Auftrag des Bundesamts für Umwelt BAFU, Dübendorf

Achilleos A, Hapeshi E, Xekoukoulotakis NP, Mantzavinos D, FattaKassinos D (2010) Factors affecting diclofenac decomposition in water by UV-A/TiO2 photocatalysis. Chem Eng J 161:53-59

Aguinaco A, Beltran FJ, Garcia-Araya JF, Oropesa A (2012) Photocatalytic ozonation to remove the pharmaceutical diclofenac from water: influence of variables. Chem Eng J 189:275-282

Alexander JT, Hai FI, Al-aboud TM (2012) Chemical coagulation-based processes for trace organic contaminant removal: current state and future potential. J Environ Manag 111:195-207

Alturki AA, Tadkaew N, McDonald JA, Khan SJ, Price WE, Nghiem LD (2010) Combining MBR and NF/RO membrane filtration for the removal of trace organics in indirect potable water reuse applications. J Membr Sci 365:206-215

Amorisco A, Locaputo V, Pastore C, Mascolo G (2013) Identification of low molecular weight organic acids by ion chromatography/hybrid quadrupole time-of-flight mass spectrometry during Uniblu-A ozonation. Rapid Commun Mass Spectrom 27:187-199

Andreozzi R, Marotta R, Paxéus N (2003) Pharmaceuticals in STP effluents and their solar photodegradation in aquatic environment. Chemosphere 50:1319-1330

Antoniou MG, Hey G, Rodriguez Vega S, Spiliotopoulou A, Fick J, Tysklind M, Jansen J, Andersen HR (2013) Required ozone doses 
for removing pharmaceuticals from wastewater effluents. Sci Total Environ 456-457:42-49

Arnold KE, Boxall ABA, Brown AR, Cuthbert RJ, Gaw S, Hutchinson TH, Jobling S, Madden JC, Metcalfe CD, Naidoo V, Shore RF, Smits JE, Taggart MA, Thompson HM (2013) Assessing the exposure risk and impacts of pharmaceuticals in the environment on individuals and ecosystems. Biol Lett 9:20130492

Ashton D, Hilton M, Thomas KV (2004) Investigating the environmental transport of human pharmaceuticals to streams in the United Kingdom. Sci Total Environ 333:167-184

Augugliaro V, Bellardita M, Loddo V, Palmisano G, Palmisano L, Yurdaka S (2012) Overview on oxidation mechanisms of organic compounds by $\mathrm{TiO}_{2}$ in heterogeneous photocatalysis. J Photochem Photobiol, C 13:224-245

Baranauskaite I, Dvarioniene J (2014) Presence and detection of pharmaceutical substances (diclofenac, 17- $\beta$-estradiol, 17- $\alpha$ ethinylestradiol) in the environment. Future challenges for Lithuania. Environ Res Eng Manag 2:25-40

Barjenbruch M, Firk W, Fröhlich AP (2014) Possibilities for the elimination of trace organic elements in municipal wastewater treatment plants (Möglichkeiten der Elimination von organischen Spurenstoffen in kommunalen Kläranlagen). queryKA Abwasser, Abfall 61:861-875 (in German)

Baronti C, Curini R, D’Ascenzo G, Di Corcia A, Gentili A, Samperi R (2000) Monitoring natural and synthetic estrogens at activated sludge sewage treatment plants and in a receiving river water. Environ Sci Technol 34:5059-5066

Barrera-Díaz C, Cañizares P, Fernández FJ, Natividad R, Rodrigo MA (2014) Electrochemical advanced oxidation processes: an overview of the current applications to actual industrial effluents. J Mex Chem Soc 58:256-275

Bartha B, Huber C, Schröder P (2014) Uptake and metabolism of diclofenac in Thypha ssp.- - how plants cope with human pharmaceutical pollution. Plant Sci 227:12-20

Behera SK, Kim HW, Oh JE, Park SH (2011) Occurrence and removal of antibiotics, hormones and several other pharmaceuticals in wastewater treatment plants for the largest industrial city of Korea. Sci Total Environ 409:4351-4360

Belfroid AC, Van der Horst A, Vethaak AD, Schäfer AJ, Rijs GB, Wegener J, Cofino WP (1999) Analysis and occurrence of estrogenic hormones and their glucuronides in surface water and waste water in The Netherlands. Sci Total Environ 225:101-108

Bellona C, Drewes JE, Xu P, Amy G (2004) Factors affecting the rejection of organic solutes during NF/RO treatment - a literature review. Water Res 38:2795-2809

Bellona C, Drewes JE, Oelker G, Luna J, Filteau G, Amy G (2008) Comparing nanofiltration and reverse osmosis for drinking water augmentation. J Am Water Works Assoc 100:102-116

Beltrán FJ, Pocostales JP, Alvarez PM, Jaramillo J (2009) Mechanism and kinetic considerations of TOC removal from the powdered activated carbon ozonation of diclofenac aqueous solutions. J Hazard Mater 169:532-538

Bendz D, Paxéus NA, Ginn TR, Loge FJ (2005) Occurrence and fate of pharmaceutically active compounds in the environment, a case study: Höje River in Sweden. J Hazard Mater 122:195-204

Benner J, Helbling DE, Kohler H-P, Wittebol J, Kaiser E, Prasse C, Ternes TA, Albers CN, Aamand J, Horemans B, Springael D, Walravens E, Boon N (2013) Is biological treatment a viable alternative for micropollutant removal in drinking water treatment processes? Water Res 47:5955-5976

Bignert A, Danielsson S, Faxneld S, Miller A, Nyberg E (2013) Comments concerning the National Swedish Contaminant Monitoring Program in Marine Biota, 2013. Report Nr. 1:2013 to the Swedish EPA, Swedish Museum of Natural History, Stockholm.
Bodzek M, Dudziak M (2006) Elimination of steroidal sex hormones by conventional water treatment and membrane processes. Desalination 198:24-32

Boehler M, Zwickenpflug B, Hollender J, Ternes T, Joss A, Siegrist H (2012) Removal of micropollutants in municipal wastewater treatment plants by powder-activated carbon. Water Sci Technol 66: 2115-2121

Borrely SI, Cruz AC, Del Mastro NL, Sampa MHO, Somessary ES (1998) Radiation processing of sewage and sludge. Prog Nucl Energy 33:3-21

Brillas E, Martinez-Huitle CA (eds) (2011) Synthetic diamond filmspreparation, electrochemistry, characterization and applications. Wiley, Chichester

Brillas E, Garcia-Segura S, Skoumal M, Arias C (2010) Electrochemical incineration of diclofenac in neutral aqueous medium by anodic oxidation using $\mathrm{Pt}$ and boron-doped diamond anodes. Chemosphere 79:605-612

Caldwell DJ, Mastrocco F, Hutchinson TH, Länge R, Heijerick D, Janssen C, Anderson PD, Sumpter JP (2008) Derivation of an aquatic predicted no-effect concentration for the synthetic hormone, 17 alpha-ethinyl estradiol. Environ Sci Technol 42:7046-7054

Caldwell DJ, Mastrocco F, Anderson PD, Länge R, Sumpter JP (2012) Predicted no-effect concentrations for the steroid estrogens estrone, $17 \beta$-estradiol, estriol, and $17 \alpha$-ethinylestradiol. Environ Toxicol Chem 31:1396-1406

Calza P, Sakkas VA, Medana C et al (2006) Photocatalytic degradation study of diclofenac over aqueous $\mathrm{TiO}_{2}$ suspensions. Appl Catal B Environ 67:197-205

Carballa M, Omil F, Lema JM, Llompart M, García C, Rodríguez I, Gómez M, Ternes T (2004) Behavior of pharmaceuticals, cosmetics and hormones in a sewage treatment plant. Water Res 38:2918-2926

Carballa M, Omil F, Lema JM, Ternes T (2005) Removal of cosmetic ingredients and pharmaceuticals in sewage primary treatment. Water Res 39:4790-4796

Carballa M, Omil F, Lema JM (2007) Calculation methods to perform mass balances of micropollutants in sewage treatment plants. Application to pharmaceutical and personal care products (PPCPs). Environ Sci Technol 41:884-890

Carballa M, Omil F, Lema JM (2008) Comparison of predicted and measured concentrations of selected pharmaceuticals, fragrances and hormones in Spanish sewage. Chemosphere 72:1118-1123

Carmona E, Andreub V, Picó Y (2014) Occurrence of acidic pharmaceuticals and personal care products in Turia River Basin: from waste to drinking water. Sci Total Environ 484:53-63

Cartinella JL, Cath TY, Flynn MT, Miller GC, Hunter KW, Childress AE (2006) Removal of natural steroid hormones from wastewater using membrane contactor processes. Environ Sci Technol 40:7381-7386

Caupos E, Mazellier P, Croue JP (2011) Photodegradation of estrone enhanced by dissolved organic matter under simulated sunlight. Water Res 45:3341-3350

CDE 2015/495, Commission Implementing Decision (EU) 2015/495. Official Journal of the European Union, L78 (2015), pp. 40-42

Chiha M, Merouani S, Hamdaoui O, Baup S, Bondrexon N, Petrier C (2010) Modeling of ultrasonic degradation of non-volatile organic compounds by Langmuir-type kinetics. Ultrason Sonochem 17: 773-782

Chowdhury P, Viraraghavan T, Srinivasan A (2010) Biological treatment processes for fish processing wastewater-a review. Bioresour Technol 101:439-444

Christensen A, Gurol MD, Garoma T (2009) Treatment of persistent organic compounds by integrated advanced oxidation processes and sequential batch reactor. Water Res 43:3910-3921

Clara M, Strenn B, Gans O, Martinez E, Kreuzinger N, Kroiss H (2005) Removal of selected pharmaceuticals, fragrances and endocrine disrupting compound in a membrane bioreactor and conventional wastewater treatment plants. Water Res 39:4797-4807 
Coelho AD, Sans C, Agüera A, Gómez MJ, Esplugas S, Dezotti M (2009) Effects of ozone pre-treatment on diclofenac: intermediates, biodegradability and toxicity assessment. Sci Total Environ 407:35723578

Coleman HM, Routledge EJ, Sumpter JP, Eggins BR, Byrne JA (2004) Rapid loss of estrogenicity of steroid estrogens by UVA photolysis and photocatalysis over an immobilised titanium dioxide catalyst. Water Res 38:3233-3240

Collado N, Rodriguez-Mozaz S, Gros M, Rubirola A, Barceló D, Comas J, Rodriguez-Roda I, Buttiglieri G (2014) Pharmaceuticals occurrence in a WWTP with significant industrial contribution and its input into the river system. Environ Pollut 185:202-212

Comninellis C, Kapalka A, Malato S, Parsons SA, Poulios I, Mantzavinos D (2008) Advanced oxidation processes for water treatment: advances and trends for R\&D. J Chem Technol Biotechnol 83:769-776

Coria G, Nava JL, Carreno G (2014) Electrooxidation of diclofenac in synthetic pharmaceutical wastewater using an electrochemical reactor equipped with a boron doped diamond electrode. J Mex Chem Soc 58:303-308

Cortazar E, Bartolome L, Delgado A, Etxebarria N, Fernandez LA, Usoibaga A, Zuloaga O (2005) Optimisation of microwaveassisted extraction for the determination of nonylphenols and phthalate esters in sediment samples and comparison with pressurised solvent extraction. Anal Chim Acta 534:247-257

Dai CM, Geissen SU, Zhang JL, Zhang YJ, Zhou XF (2011) Selective removal of diclofenac from contaminated water using molecularly imprinted polymer microspheres. Environ Pollut 159:1660-1666

Daughton CG (2001) Pharmaceuticals and personal care products in the environment: overarching issues and overview. In: Daughton CG, Jones-Lepp TL (eds) Pharmaceuticals and personal care products in the environment: scientific and regulatory issues. ACS Symp Ser 791, Washington, pp 2-38

De la Cruz N, Giménez J, Esplugas S, Grandjean D, de Alencastro LF, Pulgarín C (2012) Degradation of 32 emergent contaminants by UV and neutral photo-Fenton in domestic wastewater effluent previously treated by activated sludge. Water Res 46: 1947-1957

De la Cruz N, Esquius L, Grandjean D, Magnet A, Tungler A, de Alencastro LF, Pulgarín C (2013) Degradation of emergent contaminants by $\mathrm{UV}, \mathrm{UV} / \mathrm{H}_{2} \mathrm{O}_{2}$ and neutral photo-Fenton at pilot scale in a domestic wastewater treatment plant. Water Res 47:5836-5845

De Laurentiis A, Prasse C, Ternes TA, Minella M, Maurino V, Minero C, Sarakha M, Brigante M, Vione D (2014) Assessing the photochemical transformation pathways of acetaminophen relevant to surface waters: transformation kinetics, intermediates, and modeling. Water Res 53:235-248

DeMaleki Z, Lai EPC, Dabek-Zlotorzynska E (2010) Capillary electrophoresis characterization of molecularly imprinted polymer particles in fast binding with $17 \beta$-estradiol. J Sep Sci 33:2796-2803

Deng A, Himmelsbach M, Zhu QZ, Frey S, Sengl M, Buchberger W, Niessner R, Knopp D (2003) Residue analysis of the pharmaceutical diclofenac in different water types using ELISA and GC-MS. Environ Sci Technol 37:3422-3429

Dobrin D, Bradu C, Magureanu M, Mandache NB, Parvulescu VI (2013) Degradation of diclofenac in water using a pulsed corona discharge. Chem Eng J 234:389-396. doi:10.1155/2011/989270

Drewes JE, Bellona C, Oedekoven M, Xu P, Kim TU, Amy G (2005) Rejection of wastewater-derived micropollutants in high-pressure membrane applications leading to indirect portable reuse. Environ Prog 24:400-409

Dudziak M, Bodzek M (2009) Selected factors affecting the elimination of hormones from water using nanofiltration. Desalination 240:236243
EC (2003) Technical guidance document on risk assessment, European Commission Joint Research Centre. Publication EUR 20418 EN/3, Environmental Risk Assessment 2003, Part II, Chapter 3.

Estonian State Agency of Medicines (2013) Baltic statistics on medicines 2010-2012. Sales Statistics 2010-2012, Tartu

EU Directive 2013/39/EU of the European Parliament and of the Council. Available in www format: http://eur-lex.europa.eu/LexUriServ/ LexUriServ.do?uri= OJ:L:2013:226:0001:0017:EN:PDF.

Falas P, Baillon-Dhumes A, Andersen HR, Ledin A, la Cour Jansen J (2012) Suspended biofilm carrier and activated sludge removal of acidic pharmaceuticals. Water Res 46:1167-1175

Falas P, Longrée P, la Cour Jansen J, Siegrist H, Hollender J, Joss A (2013) Micropollutant removal by attached and suspended growth in a hybrid biofilm-activated sludge process. Water Res 47:44984506

Fent K, Weston AA, Caminada D (2006) Ecotoxicology of human pharmaceuticals. Aquat Toxicol 76:122-159

Fernandez-Fontaina E, Omil F, Lema JM, Carballa M (2012) Influence of nitrifying conditions on the biodegradation and sorption of emerging micropollutants. Water Res 46:5434-5344

Ferrari F, Gallipoli A, Balderacchi M, Ulaszewska MM, Capri E, Trevisan M (2011) Exposure of the main Italian river basin to pharmaceuticals. J Toxicol: Article ID 989270, 11 pages.

Forrez I, Carballa M, Noppe H, De Brabander H, Boon N, Verstraete W (2009) Influence of manganese and ammonium oxidation on the removal of $17 \alpha$-ethinylestradiol (EE2). Water Res 43:77-86

Forrez I, Carballa M, Verbeke K, Vanhaecke L, Schlüsener M, Ternes T, Boon N, Verstraete W (2010) Diclofenac oxidation by biogenic manganese oxides. Environ Sci Technol 44:3449-3454

Fraquelli G, Giandrone R (2003) Reforming the wastewater treatment sector in Italy: implications of plant size, structure, and scale economies. Water Resour Res 39(10):WES11-WES17

Fryda M, Matthée T, Mulcahy S, Hampel A, Schäfer L, Tröster I (2003) Fabrication and application of Diachem ${ }^{\mathbb{R}}$ electrodes. Diam Relat Mater 12:1950-1956

Fukuhara T, Iwasaki S, Kawashima M, Shinohara O, Abe I (2006) Adsorbability of estrone and $17 \beta$-estradiol in water onto activated carbon. Water Res 40:241-248

Gabet-Giraud V, Miege C, Jacquet R, Coquery M (2014) Impact of wastewater treatment plants on receiving surface waters and a tentative risk evaluation: the case of estrogens and beta blockers. Environ Sci Pollut Res 21:1708-1722

García-Araya JF, Beltrán FJ, Aguinaco A (2010) Diclofenac removal from water by ozone and photolytic $\mathrm{TiO}_{2}$ catalysed processes. $\mathrm{J}$ Chem Technol Biotechnol 85:798-804

Gatidou G, Thomaidis NS, Stasinakis AS, Lekkas TD (2007) Simultaneous determination of the endocrine disrupting compounds nonylphenol, nonylphenol ethoxylates, triclosan and bisphenol A in wastewater and sewage sludge by gas chromatography-mass spectrometry. J Chromatogr A 1138:32-41

Genius M, Manioudaki M, Mokas E, Pantagakis E, Tampakakis D, Tsagarakis KP (2005) Estimation of willingness to pay for wastewater treatment. Water Sci Technol Water Supply 5(6):105-113

Genius M, Menegaki AN, Tsagarakis KP (2012) Assessing preferences for wastewater treatment in a rural area using choice experiments. Water Resour Res 48(4):W0450

Gerrity D, Gamage S, Holady JC, Mawhinney DB, Quiñones O, Trenholm RA, Snyder SA (2011) Pilot-scale evaluation of ozone and biological activated carbon for trace organic contaminant mitigation and disinfection. Water Res 45:2155-2165

Getoff N (2002) Factors influencing the efficiency of radiation-induced degradation of water pollutants. Radiat Phys Chem 65:437-446

Ghauch A, Abou Assi H, Bdeir S (2010) Aqueous removal of diclofenac by plated elemental iron: bimetallic systems. J Hazard Mater 182: 64-74 
Ghauch A, Abou Assi H, Baydoun H, Tuqan AM, Bejjani A (2011) Fe ${ }^{0}$ based trimetallic systems for the removal of aqueous diclofenac: mechanism and kinetics. Chem Eng J 172:1033-1044

Godfrey AR, Brenton AG (2012) Accurate mass measurements and their appropriate use for reliable analyte identification. Anal Bioanal Chem 404:1159-1164

Gorga M, Petrovic M, Barceló D (2013) Multi-residue analytical method for the determination of endocrine disruptors and related compounds in river and waste water using dual column liquid chromatography switching system coupled to mass spectrometry. J Chromatogr A 1295:57-66

Gracia-Lor E, Sancho JV, Hernández F (2010) Simultaneous determination of acidic, neutral and basic pharmaceuticals in urban wastewater by ultra high-pressure liquid chromatography-tandem mass spectrometry. J Chromatogr A 1217:622-632

Gracia-Lor E, Sancho JV, Hernández F (2011) Multi-class determination of around 50 pharmaceuticals, including 26 antibiotics, in environmental and wastewater samples by ultra-high performance liquid chromatography-tandem mass spectrometry. J Chromatogr A 1218:2264-2275

Gros M, Petrović M, Barceló D (2006a) Development of a multi-residue analytical methodology based on liquid chromatography-tandem mass spectrometry (LC-MS/MS) for screening and trace level determination of pharmaceuticals in surface and wastewaters. Talanta 70: 678-690

Gros M, Petrović M, Barceló D (2006b) Multi-residue analytical methods using LC-tandem MS for the determination of pharmaceuticals in environmental and wastewater samples: a review. Anal Bioanal Chem 386:941-952

Gros M, Petrović M, Barceló D (2009) Tracing pharmaceutical residues of different therapeutic classes in environmental waters by using liquid chromatography/quadrupole-linear ion trap mass spectrometry and automated library searching. Anal Chem 81:898-912

Gros M, Rodríguez-Mozaz S, Barceló D (2012) Fast and comprehensive multi-residue analysis of a broad range of human and veterinary pharmaceuticals and some of their metabolites in surface and treated waters by ultra-high-performance liquid chromatography coupled to quadrupole-linear ion trap tandem mass spectrometry. J Chromatogr A $1248: 104-121$

Grover DP, Zhou JL, Frickers PE, Readman JW (2011) Improved removal of estrogenic and pharmaceutical compounds in sewage effluent by full scale granular activated carbon: impact on receiving river water. J Hazard Mater 185:1005-1011

Grung M, Heimstad ES, Moe M, Schlabach M, Svenson A, Thomas KV, Woldegiorgis A (2007) Human and veterinary pharmaceuticals, narcotics, and personal care products in the environment. Current state of knowledge and monitoring requirements. Norwegian Climate and Pollution Agency (Klif) report TA-2325/2007.

Grung M, Kallqvist T, Sakshaug S, Skurtveit S, Thomas KV (2008) Environmental assessment of Norwegian priority pharmaceuticals based on the EMEA guideline. Ecotoxicol Environ Saf 71:328-340

Güyer GT, Ince NH (2011) Degradation of diclofenac in water by homogeneous and heterogeneous sonolysis. Ultrason Sonochem 18:114 119

Halling-Sorensen B, Nors Nielsen S, Lanzky P, Ingerslev F, Holten Lutzhoft HC, Jorgensen SE (1998) Occurrence, fate and effects of pharmaceutical substances in the environment-a review. Chemosphere 36:357-393

Hartmann J, Bartels P, Mau U, Witter M, von Tümpling W, Hofmann J, Nietzschmann E (2008) Degradation of the drug diclofenac in water by sonolysis in presence of catalysts. Chemosphere 70:453-454

Heberer T (2002a) Tracking persistent pharmaceutical residues from municipal sewage to drinking water. J Hydrol 266:175-189

Heberer T (2002b) Occurrence, fate and removal of pharmaceutical residues in the aquatic environment: a review of recent research data. Toxicol Lett 131:5-17
Henze M, Gujer W, Mino T, van Loosdrecht MCM (2000) Activated sludge models ASM1, ASM2, ASM2d and ASM3. Scientific and technical report No. 9. IWA Publishing, London

Hernández-Leal L, Temmink H, Zeeman G, Buisman CJN (2011) Removal of micropollutants from aerobically treated grey water via ozone and activated carbon. Water Res 45:2887-2896

Hernandez-Sancho F, Molinos-Senante M, Sala-Garrido R (2011) Cost modelling for wastewater treatment processes. Desalination 268(13): $1-5$

Hernando MD, Mezcua M, Fernández-Alba AR, Barceló D (2006) Environmental risk assessment of pharmaceutical residues in wastewater effluents, surface waters and sediments. Talanta 69(2):334 342

Hilton MJ, Thomas KV (2004) Determination of selected human pharmaceutical compounds in effluent and surface water samples by high-performance liquid chromatography-electrospray tandem mass spectrometry. J Chromatogr A 1015:129-141

Holbrook RD, Love NG, Novak JT (2004) Sorption of 17b-estradiol and 17 a-ethinylestradiol by colloidal organic carbon derived from biological wastewater treatment systems. Environ Sci Technol 38: 3322-3329

Hollender J, Zimmermann SG, Koepke S, Krauss M, McArdell CS, Ort C, Singer H, von Gunten U, Siegrist H (2009) Elimination of organic micropollutants in a municipal wastewater treatment plant upgraded with a full-scale post-ozonation followed by a sand filtration. Environ Sci Technol 38:5177-5186

Homlok R, Takács E, Wojnárovits L (2011) Elimination of diclofenac from water using irradiation technology. Chemosphere 85:603-608

Huang YX, Liu XW, Sun XF, Sheng GP, Zhang YY, Yan GM et al (2011) A new cathodic electrode deposit with palladium nanoparticles for cost-effective hydrogen production in a microbial electrolysis cell. Int J Hydrog Energy 36:2773-2776

Huber MM, Canonica S, Park GY, Von Gunthen U (2003) Oxidation of pharmaceuticals during ozonation and advanced oxidation processes. Environ Sci Technol 37:1016-1024

Huber MM, Göbel A, Joss A, Hermann N, Löffler D, Mcardell CS, Ried A, Siegrist H, Ternes TA, von Gunten U (2005a) Oxidation of pharmaceuticals during ozonation of municipal wastewater effluents: a pilot study. Environ Sci Technol 39:4290-4299

Huber MM, Korhonen S, Ternes TA, von Gunten U (2005b) Oxidation of pharmaceuticals during water treatment with chlorine dioxide. Water Res 39:3607-3617

Huber C, Bartha B, Schröder P (2012) Metabolism of diclofenac in plants-hydroxylation is followed by glucose conjugation. $\mathrm{J}$ Hazard Mater 243:250-256

INFARMED (2012) Medicine statistics of 2011. Direcção de Economia do Medicamento e Produtos de Saúde, Lisboa, pp 53-55

IPCC (1996) Council Directive 96/61/EC concerning integrated pollution prevention and control. EU, Official Journal L 257, 10 October 1996, pp. 26-40.

Janex-Habibi ML, Huyard V, Esperanza M, Bruchet A (2009) Reduction of endocrine disruptor emissions in the environment: the benefit of wastewater treatment. Water Res 43:1565-1576

Jarošová B, Bláha L, Giesy JP, Hilscherová K (2014) What level of estrogenic activity determined by in vitro assays in municipal waste waters can be considered as safe? Rev Environ Int 64:98-109

Jelic A, Fatone F, Di Fabio S, Petrovic M, Cecchi F, Barcelo D (2012) Tracing pharmaceuticals in a municipal plant for integrated wastewater and organic solid waste treatment. Sci Total Environ 433:352361

Jiskra M (2008) Fate of the pharmaceutical diclofenac in the aquatic environment. Term paper 21. Biogeochemistry and Pollutant Dynamics, ETH Zurich. pp. 1-16.

Jones OAH, Green PG, Voulvoulis N, Lester JN (2007) Questioning the excessive use of advanced treatments to remove organic 
micropollutants from wastewater. Environ Sci Technol 41:50855089

Joseph L, Heo J, Park JG, Flora JRV, Yoon Y (2011) Adsorption of bisphenol A and $17 \alpha$-ethinyl estradiol on single walled carbon nanotubes from seawater and brackish water. Desalination 281:6874

Joss A, Andersen H, Ternes T, Richle PR, Siegrist H (2004) Removal of estrogens in municipal wastewater treatment under aerobic and anaerobic conditions: consequences for plant optimization. Environ Sci Technol 38:3047-3055

Joss A, Keller E, Alder AC, Göbel A, McArdell CS, Ternes T, Siegrist H (2005) Removal of pharmaceuticals and fragrances in biological wastewater treatment. Water Res 39:3139-3152

Joss A, Zabczynski S, Göbel A, Hoffmann B, Löffler D, McArdell CS, Ternes TA, Thomsen A, Siegrist H (2006) Biological degradation of pharmaceuticals in municipal wastewater treatment: proposing a classification scheme. Water Res 40:1686-1696

Joss A, Siegrist H, Ternes TA (2008) Are we about to upgrade wastewater treatment for removing organic micropollutants? Water Sci Technol 57:251-255

Kallio JM, Lahti M, Oikari A, Kronberg L (2010) Metabolites of the aquatic pollutant diclofenac in fish bile. Environ Sci Technol 44: 7213-7219

Karpova T, Preis S, Kallas J (2007) Selective photocatalytic oxidation of steroid estrogens in water treatment: urea as co-pollutant. J Hazard Mater 146:465-471

Kasprzyk-Hordern B, Dinsdale RM, Guwy AJ (2008) The occurrence of pharmaceuticals, personal care products, endocrine disruptors and illicit drugs in surface water in South Wales, UK. Water Res 42: 3498-3518

Kasprzyk-Hordern B, Dinsdale RM, Guwy AJ (2009) The removal of pharmaceutical, personal care products, endocrine disruptors and illicit drugs during wastewater treatment and its impact on the quality of receiving waters. Water Res 43: 363-368

Kimura A, Taguchi M, Ohtani Y et al (2007a) Treatment of wastewater having estrogen activity by ionizing radiation. Radiat Phys Chem 76:699-706

Kimura K, Hara H, Watanabe Y (2007b) Elimination of selected acidic pharmaceuticals from municipal wastewater by an activated sludge system and membrane bioreactors. Environ Sci Technol 41:37083714

Kind T, Fiehn O (2010) Advances in structure elucidation of small molecules using mass spectrometry. Bioanal Rev 2:23-60

Kolarova J, Zlabek V, Grabic R, Golovko O, Grabicova K, Burkina V, Randak T (2013) The effect of environmentally relevant concentration of selected PPCPs on fish cell lines. Toxicol Lett 221:S161S161

Kosma CI, Lambropoulou DA, Albanis TA (2014) Investigation of PPCPs in wastewater treatment plants in Greece: occurrence, removal and environmental risk assessment. Sci Total Environ 466-467: $421-438$

Kotchen M, Kallaos J, Wheeler K, Wong C, Zahller M (2009) Pharmaceuticals in wastewater: behavior, preferences, and willingness to pay for a disposal program. J Environ Manag 90(3):14761482

Kotyza J, Soudek P, Kafka Z, Vaněk T (2010) Phytoremediation of pharmaceuticals - preliminary study. Int J Phytoremediation 12:306316

Kovalova L, Siegrist H, Singer H, Wittmer A, McArdell CS (2012) Hospital wastewater treatment by membrane bioreactor: performance and efficiency for organic micropollutant elimination. Environ Sci Technol 46:1536-1545

Kovalova L, Siegrist H, Von Gunten U, Eugster J, Hagenbuch M, Wittmer A, Moser R, McArdell CS (2013) Elimination of micropollutants during post-treatment of hospital wastewater with powdered activated carbon, ozone, and UV. Environ Sci Technol 47: 7899-7908

Koyuncu I, Arikan OA, Wiesner MR, Rice C (2008) Removal of hormones and antibiotics by nanofiltration membranes. J Membr Sci 309:94-101

Kraft A, Stadelmann M, Blaschke M (2003) Anodic oxidation with doped diamond electrodes: a new advanced oxidation process. J Hazard Mater 103:247-261

Krauss M, Singer H, Hollender J (2010) LC-high resolution MS in environmental analysis: from target screening to the identification of unknowns. Anal Bioanal Chem 397:943-951

Kruglova A, Ahlgren P, Korhonen N, Rantanen P, Mikola A, Krug RV (2014) Biodegradation of ibuprofen, diclofenac and carbamazepine in nitrifying activated sludge under $12{ }^{\circ} \mathrm{C}$ temperature conditions. Sci Total Environ 499:394-401

Kumar AK, Mohan SV (2011) Endocrine disruptive synthetic estrogen (17 $\alpha$-ethinylestradiol) removal from aqueous phase through batch and column sorption studies: mechanistic and kinetic analysis. Desalination 276:66-74

Kumar AK, Mohan SV (2012) Removal of natural and synthetic endocrine disrupting estrogens by multi-walled carbon nanotubes (MWCNT) as adsorbent: kinetic and mechanistic evaluation. Sep Purif Technol 87:22-30

Lai KM, Johnson KL, Scrimshaw MD, Lester JN (2000) Binding of waterborne steroid estrogens to solid phases in river and estuarine systems. Environ Sci Technol 34:3980-3994

Lai EPC, De Maleki Z, Wu S (2010) Characterization of molecularly imprinted and nonimprinted polymer submicron particles specifically tailored for removal of trace $17 \beta$-estradiol in water treatment. J Appl Polym Sci 116:1499-1508

Larsen TA, Lienert J, Joss A, Siegrist H (2004) How to avoid pharmaceuticals in the aquatic environment. J Biotechnol 113:295-304

Le Noir M, Lepeuple AS, Guieysse B, Mattiasson B (2007) Selective removal of $17 \beta$-estradiol at trace concentration using a molecularly imprinted polymer. Water Res 41:2825-2831

Lekkerkerker-Teunissen K, Benotti MJ, Snyder SA, van Dijk HC (2012) Transformation of atrazine, carbamazepine, diclofenac and sulfamethoxazole by low and medium pressure $\mathrm{UV}$ and $\mathrm{UV} / \mathrm{H}_{2} \mathrm{O}_{2}$ treatment. Sep Purif Technol 96:33-43

Letzel M, Metzner G, Letzel T (2009) Exposure assessment of the pharmaceutical diclofenac based on long term measurements of the aquatic input. Environ Int 35:363-368

Leusch FDL, De Jager C, Levi Y, Lim R, Puijker L, Sacher F, Tremblay LA, Wilson VS, Chapman HF (2010) Comparison of five in vitro bioassays to measure estrogenic activity in environmental waters. Environ Sci Technol 44:3853-3860

Little JL, Cleven CD, Brown SD (2011) Identification of "known unknowns" utilizing accurate mass data and Chemical Abstracts Service databases. J Am Soc Mass Spectrom 22:348-359

Little JL, Williams AJ, Pshenichnov A, Tkachenko V (2012) Identification of "known unknowns" utilizing accurate mass data and ChemSpider. J Am Soc Mass Spectrom 23:179-185

Logar I, Brouwer R, Maurer M, Ort C (2014) Cost-benefit analysis of the Swiss national policy on reducing micropollutants in treated wastewater. Environ Sci Technol 48(21):12500-12508

Loos R, Carvalho R, Antonio DC, Comero S, Locoro G, Tavazzi S, Paracchini B, Ghiani M, Lettieri T, Blaha L, Jarosova B, Voorspoels S, Servaes K, Haglund P, Fick J, Lindberg RH, Schwesig D, Gawlik BM (2013) EU-wide monitoring survey on emerging polar organic contaminants in wastewater treatment plant effluents. Water Res 47:6475-6487

Luo Y, Guo W, Ngo HH, Nghiem LD, Hai FI, Zhang J, Liang S, Wang XC (2014) A review on the occurrence of micropollutants in the aquatic environment and their fate and removal during wastewater treatment. Sci Total Environ 474:619-641 
Lust M, Makinia J, Stensel HD (2012) A mechanistic model for fate and removal of estrogens in biological nutrient removal activated sludge systems. Water Sci Technol 65:1130-1136

Magdeburg A, Stalter D, Schlüsener M, Ternes T, Oehlmann J (2014) Evaluating the efficiency of advanced wastewater treatment: target analysis of organic contaminants and (geno-)toxicity assessment tell a different story. Water Res 50:35-47

Mailler R, Gasperi J, Coquet Y, Deshayes S, Zedek S, Cren-Olivé C, Cartiser N, Eudes V, Bressy A, Caupos E, Moilleron R, Chebbo G, Rocher V (2014) Study of a large scale powdered activated carbon pilot: removals of a wide range of emerging and priority micropollutants from wastewater treatment plant effluents. Water Res 72:315-330

Manickum T, John W (2014) Occurrence, fate and environmental risk assessment of endocrine disrupting compounds at the wastewater treatment works in Pietermaritzburg (South Africa). Sci Total Environ 468:584-597

Marchese S, Perret D, Gentili A, Curini R, Pastori F (2003) Determination of non-steroidal anti-inflammatory drugs in surface water and wastewater by liquid chromatography-tandem mass spectrometry. Chromatographia 58:263-269

Margot J, Kienle C, Magnet A, Weil M, Rossi L, de Alencastro LF, Abegglen C, Thonney D, Chèvre N, Schärer M, Barry DA (2013) Treatment of micropollutants in municipal wastewater: ozone or powdered activated carbon? Sci Total Environ 461:480-498

Martínez-Huitle CA, Ferro S (2006) Electrochemical oxidation of organic pollutants for the wastewater treatment: direct and indirect processes. Chem Soc Rev 35:1324-1340

Martínez-Huitle CA, Quiroz Alfaro MA (2008) Recent environmental applications of diamond electrode: critical review. J Environ Eng Manag 18:155-172

Matamoros V, Salvadó V (2013) Evaluation of a coagulation/ flocculation-lamellar clarifier and filtration-UV-chlorination reactor for removing emerging contaminants at full-scale wastewater treatment plants in Spain. J Environ Manag 117:96-102

McCallum EA, Hyung H, Do TA, Huang CH, Kim JH (2008) Adsorption, desorption, and steady-state removal of $17 \beta$ - estradiol by nanofiltration membranes. J Membr Sci 319:38-43

Méndez-Arriaga F, Torres-Palma RA, Pétrier C, Esplugas S, Gimenez J, Pulgarin C (2008) Ultrasonic treatment of water contaminated with ibuprofen. Water Res 42:4243-4248

Menegaki AN, Hanley N, Tsagarakis KP (2007) The social acceptability and valuation of recycled water in Crete: a study of consumers' and farmers' attitudes. Ecol Econ 62(1):7-18

Meng Z, Yang F, Zhang X (2005) MBR focus: do nonwovens offer a cheaper option? Filtr Sep 42:28-30

Molinos-Senante M, Hernández-Sancho F, Sala-Garrido R (2013a) Economic feasibility study for intensive and extensive wastewater treatment considering greenhouse gases emissions. J Environ Manag 123:98-104

Molinos-Senante M, Reif R, Garrido-Baserba M, Hernández-Sancho F, Omil F, Poch M, Sala-Garrido R (2013b) Economic valuation of environmental benefits of removing pharmaceutical and personal care products from WWTP effluents by ozonation. Sci Total Environ 461-462:409-415

Monteith H, Andres H, Snowling S, Schraa O (2008) Modeling the fate of estrogenic hormones in municipal wastewater treatment. In: Proceedings of WEFTEC2008. Chicago, pp. 18-22.

Moreno-González R, Rodríguez-Mozaz S, Gros M, Pérez-Cánovas E, Barceló D, Leóna VM (2014) Input of pharmaceuticals through coastal surface watercourses into a Mediterranean lagoon (Mar Menor, Spain): sources and seasonal variations. Sci Total Environ 490:59-72

Murugananthan M, Yoshihara S, Rakuma T, Uehara N, Shirakashi T (2007) Electrochemical degradation of $17 \beta$-estradiol (E2) at boron-doped diamond (Si/BDD) thin film electrode. Electrochim Acta 52:3242-3249

Naddeo V, Meric S, Kassinos D, Belgiorno V, Guida M (2009) Fate of pharmaceuticals in contaminated urban wastewater effluent under ultrasonic irradiation. Water Res 43:4019-4027

Naddeo V, Belgiorno V, Kassinos D, Mantzavinos D, Meric S (2010) Ultrasonic degradation, mineralization and detoxification of diclofenac in water: optimization of operating parameters. Ultrason Sonochem 17:179-185

$\mathrm{Ng} \mathrm{HY}$, Elimelech M (2004) Influence of colloidal fouling on rejection of trace organic contaminants by reverse osmosis. J Membr Sci 244: 215-226

Nghiem LD, Schafer AI, Elimelech M (2005) Pharmaceutical retention mechanisms by nanofiltration membranes. Environ Sci Technol 39: 7698-7705

Nikolaou A, Meric S, Fatta D (2007) Occurrence patterns of pharmaceuticals in water and wastewater environments. Anal Bioanal Chem 387:1225-1234

Nowotny N, Epp B, von Sonntag C, Fahlenkamp H (2007) Quantification and modeling of the elimination behavior of ecologically problematic wastewater micropollutants by adsorption on powdered and granulated activated carbon. Environ Sci Technol 41:2050-2055

Nurmi J, Pellinen J, Rantalainen AL (2012) Critical evaluation of screening techniques for emerging environmental contaminants based on accurate mass measurements with time-of-flight mass spectrometry. J Mass Spectrom 47:303-312

Oller I, Malato S, Schanzez-Perez JA (2011) Combination of advanced oxidation processes with biological treatments for wastewater decontamination - a review. Sci Total Environ 409:4141-4166

Oosterhuis M, Sacher F, Ter Laak TL (2013) Prediction of concentration levels of metformin and other high consumption pharmaceuticals in wastewater and regional surface water based on sales data. Sci Total Environ 442:380-388

Oturan MA, Aaron J-J (2014) Advanced oxidation processes in water/ wastewater treatment: principles and applications. A review. Critic Rev Environ Sci Technol 44:2577-2641

Owen R, Jobling S (2012) Environmental science: the hidden costs of flexible fertility. Nature 485:441

Ozer AY, Turker S, Colak S et al (2013) The effects of gamma irradiation on diclofenac sodium, liposome and niosome ingredients for rheumatoid arthritis. Int Med Appl Sci 5:122-130

Pablos C, Marugán J, van Grieken R, Serrano E (2013) Emerging micropollutant oxidation during disinfection processes using UVC, UV-C $/ \mathrm{H}_{2} \mathrm{O}_{2}, \mathrm{UV}-\mathrm{A} / \mathrm{TiO}_{2}$ and UV-A $/ \mathrm{TiO}_{2} / \mathrm{H}_{2} \mathrm{O}_{2}$. Water Res 47: $1237-1245$

Pal A, Gin KHY, Lin AYC, Reinhard M (2010) Impacts of emerging organic contaminants on freshwater resources: review of recent occurrences, sources, fate and effects. Sci Total Environ 408:60626069

Patrolecco L, Ademollo N, Grenni P, Tolomei A, Barra Caracciolo A, Capri S (2013) Simultaneous determination of human pharmaceuticals in water samples by solid phase extraction and HPLC with UVfluorescence detection. Microchem J 107:165-171

Pereira AMPT, Silva LJG, Meisel LM, Lino CM, Pena A (2015) Environmental impact of pharmaceuticals from Portuguese wastewaters: geographical and seasonal occurrence, removal and risk assessment. Environ Res 136:108-119

Petrović M, Škrbić B, Živančev J, Ferrando-Climent L, Barcelo D (2014) Determination of 81 pharmaceutical drugs by high performance liquid chromatography coupled to mass spectrometry with hybrid triple quadrupole-linear ion trap in different types of water in Serbia. Sci Total Environ 468:415-428

Pikaev AK (2000) Current status of the application of ionizing radiation to environmental protection: II. Wastewater and other liquid wastes (a review). High Energy Chem 34:55-73 
Plosz BG, Langford KH, Thomas KV (2012) An activated sludge modelling framework for xenobiotic trace chemicals (ASM-X): assessment of diclofenac and carbamazepine. Biotechnol Bioeng 109: 2757-2769

Pojana G, Gomiero A, Jonkers N, Marcomini A (2007) Natural and synthetic endocrine disrupting compounds (EDCs) in water, sediment and biota of a coastal lagoon. Environ Int 33:929-936

Quintana JB, Reemtsma T (2004) Sensitive determination of acidic drugs and triclosan in surface and wastewater by ion-pair reverse-phase liquid chromatography/tandem mass spectrometry. Rapid Commun Mass Spectrom 18:765-774

Quintana JB, Carpinteiro J, Rodriguez I, Lorenzo RA, Carro AM, Cela R (2004) Determination of natural and synthetic estrogens in water by gas chromatography with mass spectrometric detection. J Chromatogr A 1024:177-185

Quintana JB, Weiss S, Reemtsma T (2005) Pathways and metabolites of microbial degradation of selected acidic pharmaceutical and their occurrence in municipal wastewater treated by a membrane bioreactor. Water Res 39:2654-2664

Rabiet M, Togola A, Brissaud F, Seidel JL, Budzinski H, Elbaz-Poulicher $\mathrm{F}$ (2006) Consequence of treated water recycling as regards pharmaceuticals and drugs in surface and groundwater in a mediumsized Mediterranean catchment. Environ Sci Technol 40:5282-5288

Racz LA, Goel RK (2009) Fate and removal of estrogens in municipal wastewater. J Environ Monit 12:58-70

Radjenović J, Jelić A, Petrović M, Barcelo D (2009) Determination of pharmaceuticals in sewage sludge by pressurized liquid extraction (PLE) coupled to liquid chromatography-tandem mass spectrometry (LC-MS/MS). Anal Bioanal Chem 393:1685-1695

Radonjić V, Šipetić T (2012) Trade and consumption of the medicinal products. Annual reports 2012. Medicines and Medical Devices Agency of Serbia, Belgrade

Rajab M, Greco G, Heim C, Helmreich B, Letzel T (2013) Serial coupling of reversed-phase and zwitterionic hydrophilic interaction LC/MS: suspects screening of diclofenac transformation products by oxidation with boron-doped diamond electrode. J Sep Sci 36:3011-3018

Reemtsma T, Weiss S, Mueller J, Petrovic M, Gonzalez S, Barcelo D, Ventura F, Knepper TP (2006) Polar pollutants entry into the water cycle by municipal wastewater: a European perspective. Environ Sci Technol 40:5451-5458

Reungoat J, Escher BI, Macova M, Keller J (2011) Biofiltration of wastewater plant effluent: effective removal of pharmaceutical and personal care products and reduction of toxicity. Water Res 45:27512762

Ribeiro A, Afonso CMM, Castro PML, Tiritan ME (2013) Enantioselective biodegradation of pharmaceuticals, alprenolol and propranolol, by an activated sludge inoculum. Ecotoxicol Environ Saf 87:108-114

Rice SL, Mitra S (2007) Microwave-assisted solvent extraction of solid matrices and subsequent detection of pharmaceuticals and personal care products (PPCPs) using gas chromatography-mass spectrometry. Anal Chim Acta 589:125-132

Rivera-Utrilla J, Sánchez-Polo M, Ángeles Ferro-García M, Prados-Joya G, Ocampo-Pérez R (2013) Pharmaceuticals as emerging contaminants and their removal from water. A review. Chemosphere 93: $1268-1287$

RIWA (2014) Die Qualität des Rheinwassers im Jahr 2013. Annual report 2013. RIWA-Rhine, Nieuwegein

Roberts PH, Thomas KV (2005) The occurrence of selected pharmaceuticals in wastewater effluent and surface waters of the lower Tyne catchment. Trends Biotechnol 23:163-167

Rogers HR (1996) Sources, behavior and fate of organic contaminants during sewage treatment and in sewage sludges. Sci Total Environ $185: 3-26$
Röhricht M, Krisam J, Weise U, Kraus UR, During RA (2009) Elimination of carbamazepine, diclofenac and naproxen from treated wastewater by nanofiltration. Clean: Soil, Air, Water 37:638-641

Röhricht M, Krisam J, Weise U, Kraus UR, Düring RA (2010) Elimination of pharmaceuticals from wastewater by submerged nanofiltration plate modules. Desalination 250:1025-1026

Rosenfeldt EJ, Linden KG (2004) Degradation of endocrine disrupting chemicals bisphenol A, ethinylestradiol, and estradiol during UV photolysis and advanced oxidation processes. Environ Sci Technol 38:5476-5483

Rosenfeldt EJ, Linden KG, Canonica S, von Gunten U (2006) Comparison of the efficiency of $* \mathrm{OH}$ radical formation during ozonation and the advanced oxidation processes $\mathrm{O}_{3} / \mathrm{H}_{2} \mathrm{O}_{2}$ and $\mathrm{UV} / \mathrm{H}_{2} \mathrm{O}_{2}$. Water Res 40:3695-3704

Rosenfeldt EJ, Chen PJ, Kullman S, Linden KG (2007) Destruction of estrogenic activity in water using UV advanced oxidation. Sci Total Environ 377:105-113

Sacher F, Ehmann M, Gabriel S, Graf C, Brauch HJ (2008) Pharmaceutical residues in the river Rhine-results of a onedecade monitoring programme. J Environ Monit 10:664-670

Sahar E, David I, Gelman Y, Chikurel H, Aharoni A, Messalem R (2011) The use of RO to remove emerging micropollutants following CAS/ UF or MBR treatment of municipal wastewater. Desalination 273: $142-147$

Salgado R, Noronha JP, Oehmen A, Carvalho G, Reis MA (2010) Analysis of 65 pharmaceuticals and personal care products in 5 wastewater treatment plants in Portugal using a simplified analytical methodology. Water Sci Technol 62:2862-2871

Salgado R, Marques R, Noronha JP, Carvalho G, Oehmen A, Reis MA (2012) Assessing the removal of pharmaceuticals and personal care products in a full-scale activated sludge plant. Environ Sci Pollut Res 19:1818-1827

Samaras VG, Stasinakis AS, Mamais D, Thomaidis NS, Lekkas TD (2013) Fate of selected pharmaceuticals and synthetic endocrine disrupting compounds during wastewater treatment and sludge anaerobic digestion. J Hazard Mater 244:259-267

Santos LHMLM, Gros M, Rodriguez-Mozaz S, Delerue-Matos C, Pena A, Barceló D, Montenegro MCBSM (2013) Contribution of hospital effluents to the load of pharmaceuticals in urban wastewaters: identification of ecologically relevant pharmaceuticals. Sci Total Environ 461:302-316

Sari S, Ozdemir G, Yangin-Gomec C, Zengin GE, Topuz E, Aydin E, Pehlivanoglu-Mantas E, Kutman O, Tas D (2014) Seasonal variation of diclofenac concentration and its relation with wastewater characteristics at two municipal wastewater treatment plants in Turkey. J Hazard Mater 272:155-164

Schäfer AI, Akanyeti I, Semião AJC (2011) Micropollutant sorption to membrane polymers: a review of mechanisms for estrogens. Adv Colloid Interf Sci 164:100-117

Schröder P (2007) Exploiting plant metabolism for phytoremediation of organic xenobiotics. In: Willey N (ed) Phytoremediation: methods and reviews. Humana, Totowa, pp 251-265

Schröder P, Collins CJ (2002) Conjugating enzymes involved in xenobiotic metabolism of organic xenobiotics in plants. Int $\mathrm{J}$ Phytoremediation 4:247-265

Schröder P, Navarro Avino J, Azaizeh H, Golan Goldhirsh A, DiGregorio S, Komives T, Langergraber G, Lenz A, Maestri E, Memon A, Ranalli A, Sebastiani L, Smrcek S, Vanek T, Vuillemier S, Wissing F (2007) Position paper: using phytoremediation technologies to upgrade waste water treatment in Europe. Environ Sci Pollut Res 14:490-497

Schwaiger J, Ferling H, Mallow U, Wintermayr H, Negele RD (2004) Toxic effects of the non-steroidal anti-inflammatory drug diclofenac. Part I Histopathological alterations and bioaccumulation in rainbow trout. Aquat Toxicol 68:141-150 
Schwarzenbach RP, Gschwend PM, Imboden DM (2003) Environmental organic chemistry. Wiley, New York

Sein MM, Zedda M, Tuerk J, Schmidt TC, Gilloch J, Von Sonntag C (2008) Oxidation of diclofenac with ozone in aqueous solution. Environ Sci Technol 42:6656-6662

Serrano D, Suarez S, Lema JM, Omil F (2010) Influence of the employment of adsorption and coprecipitation agents for the removal of PPCPs in conventional activated sludge (CAS) systems. Water Sci Technol 62:728-735

Serrano D, Suarez S, Lema JM, Omil F (2011) Removal of persistent pharmaceutical micropollutants from sewage by addition of PAC in a sequential membrane bioreactor. Water Res 43:9323-9333

Shi W, Wang L, Rousseau DPL, Lens PNL (2010) Removal of estrone, $17 \beta$-ethinylestradiol, and $17 \beta$-estradiol in algae and duckweedbased wastewater treatment systems. Environ Sci Pollut Res 17: 824-833

Shore RF, Taggart MA, Smits J, Mateo R, Richards NL, Fryday S (2014) Detection and drivers of exposure and effects of pharmaceuticals in higher vertebrates. Philos Trans R Soc B 369:20130570

Silva CP, Otero M, Esteves V (2012) Process for the elimination of estrogenic steroid hormones from water: a review. Environ Pollut 165: $38-58$

Sirés I, Brillas E (2012) Remediation of water pollution caused by pharmaceutical residues based on electrochemical separation and degradation technologies: a review. Environ Int 40:212-229

Sirés I, Brillas E, Oturan MA, Rodrigo MA, Panizza M (2014) Electrochemical advanced oxidation processes: today and tomorrow. Environ Sci Pollut Res 21:8336-8367

Škrbić B, Petrović M, Živančev J, Đurišić-Mladenović N (2014) Pharmaceutically active compounds in untreated municipal waste water. Proceedings of The International Conference Protection and Restoration of the Environment, Skiathos Island, pp 72-77

Snip LJP, Flores-Alsina X, Plósz BG, Jeppsson U, Gernaey KV (2014) Modelling the occurrence, transport and fate of pharmaceuticals in wastewater systems. Environ Model Softw 62:112-127

Snyder SA, Villeneuve DL, Snyder EM, Giesy JP (2001) Identification and quantification of estrogen receptor agonists in wastewater effluents. Environ Sci Technol 35:3620-3625

Snyder SA, Adham S, Redding AM, Cannon FS, DeCarolis J, Oppenheimer J, Wert EC, Yoon Y (2007) Role of membranes and activated carbon in the removal of endocrine disruptors and pharmaceuticals. Desalination 202:156-181

Song HL, Nakano K, Taniguchi T, Nomura M, Nishimura O (2009) Estrogen removal from treated municipal effluent in small-scale constructed wetland with different depth. Bioresour Technol 100: 2945-2951

SRU (2007) The German Advisory Council on the Environment: pharmaceuticals in the environment. A statement. SRU, Vol. 12, Dessau.

Stadler LB, Ernstoff AS, Aga DS, Love NG (2012) Micropollutant data in wastewater treatment: redefining "removal". Environ Sci Technol 46:10485-10486

Stamm C, Eggen RIL, Hering JG, Hollender J, Joss A, Schärer M (2015) Micropollutant removal from wastewater: facts and decision making despite uncertainties. Environ Sci Techol 49:6374-6375

Stasinakis AS, Kordoutis CI, Tsiouma VC, Gatidou G, Thomaidis NS (2010) Removal of selected endocrine disrupters in activated sludge systems: effect of sludge retention time on their sorption and biodegradation. Bioresour Technol 101:2090-2095

Suárez S, Carballa M, Omil F, Lema JM (2008) How are pharmaceutical and personal care products (PPCPs) removed from urban wastewaters? Rev Environ Sci Biotechnol 7:125-130

Suarez S, Lema JM, Omil F (2009) Pre-treatment of hospital wastewater by coagulation-flocculation and flotation. Bioresour Technol 100: $2138-2146$
Suarez S, Lema JM, Omil F (2010) Removal of pharmaceutical and personal care products under nitrifying and denitrifying conditions. Water Res 44:3214-3224

Suarez S, Reif R, Lema JM, Omil F (2012) Mass balance of pharmaceuticals and personal care products in pilot-scale system: influence of T, SRT and recirculation ratio. Chemosphere 89:164-167

Sui Q, Huang J, Deng S, Yu G, Fan Q (2010) Occurrence and removal of pharmaceuticals, caffeine and DEET in wastewater treatment plants of Beijing, China. Water Res 44:417-426

Sweetman SC (2002) The complete drug reference, 3rd edn. Pharmaceutical Press, London

Tadkaew N, Hai FI, McDonald JA, Khan SJ, Nghiem LD (2011) Removal of trace organics by MBR treatment: the role of molecular properties. Water Res 45:2439-2451

Ternes TA (1998) Occurrence of drugs in German sewage treatment plants and rivers. Water Res 32:3245-3260

Ternes TA (2001) Pharmaceuticals and metabolites as contaminants of the aquatic environment. In: Daughton CG, Jones-Lepp TL (eds) Pharmaceuticals and personal care products in the environment: scientific and regulatory issues. ACS Symp. Ser. 791, Washington, pp 39-54

Ternes TA, Stumpf M, Mueller J, Haberer K, Wilken RD, Servos M (1999) Behavior and occurrence of estrogens in municipal sewage treatment plants-I. Investigations in Germany, Canada and Brazil. Sci Total Environ 225(1-2):81-90

Ternes TA, Stüber J, Herrmann N, McDowell D, Ried A, Kampmann M, Teiser B (2003) Ozonation: a tool for removal of pharmaceuticals, contrast media and musk fragrances from wastewater? Water Res 37:1976-1982

Ternes TA, Herrmann N, Bonerz M, Knacker T, Siegrist H, Joss A (2004a) A rapid method to measure the solidwater distribution coefficient $(\mathrm{Kd})$ for pharmaceuticals and musk fragrances in sewage sludge. Water Res 38:4075-4084

Ternes TA, Joss A, Siegrist H (2004b) Scrutinizing pharmaceuticals and personal care products in wastewater treatment. Environ Sci Technol 38:392A-399A

Terzić S, Senta I, Ahel M, Gros M, Petrović M, Barcelo D, Müller J, Knepper T, Martí I, Ventura F, Jovancić P, Jabucar D (2008) Occurrence and fate of emerging wastewater contaminants in Western Balkan Region. Sci Total Environ 399:66-77

Thomas KV, Hilton MJ (2004) The occurrence of selected human pharmaceutical compounds in UK estuaries. Mar Pollut Bull 49:436444

Thomas KV, Dye C, Schlabach M, Langford KH (2007) Source to sink tracking of selected human pharmaceuticals from two Oslo city hospitals and a wastewater treatment works. J Environ Monit 9: $1410-1418$

Tixier C, Singer HP, Oellers S, Müller SR (2003) Occurrence and fate of carbamazepine, clofibric acid, diclofenac, ibuprofen, ketoprofen, and naproxen in surface waters. Environ Sci Technol 37:1061-1068

Triebskorn R, Casper H, Heyd A, Eikemper R, Kohler H-R, Schwaiger J (2004) Toxic effects of the non-steroidal anti-inflammatory drug diclofenac. Part II. Cytological effects in liver, kidney, gills and intestine of rainbow trout (Oncorhynchus mykiss). Aquat Toxicol 68:151-166

Trojanowicz M, Bojanowska-Czajka A, Gciuk G et al (2012) Application of ionizing radiation in decomposition of selected organic pollutants in water. Eur Water 39:15-26

Tröster I, Schäfer L, Fryda M, Matthée T (2004) Electrochemical advanced oxidation process using DiaChem ${ }^{\circledR}$ electrodes. Water Sci Technol 49:207-212

Trueman RJ, Erber L (2013) Invasive species may offer advanced phytoremediation of endocrine disrupting chemicals in aquatic ecosystems. Emirates J Food Agric 25:648-656 
Tsagarakis KP, Mara DD, Angelakis AN (2003) Application of cost criteria for selection of municipal wastewater treatment systems. Water Air Soil Pollut 142(1-4):187-210

Urase T, Sato K (2007) The effect of deterioration of nanofiltration membrane on retention of pharmaceuticals. Desalination 202:385-391

Vedenyapina MD, Strel'tsova ED, Davshan NA, Vedenyapin AA (2011) Study of the electrochemical degradation of diclofenac on a borondoped diamond electrode by UV spectroscopy. Russ J Appl Chem 84:204-207

Verlicchi P, Al Aukidy M, Zambello E (2012) Occurrence of pharmaceutical compounds in urban wastewater: removal, mass load and environmental risk after a secondary treatment - a review. Sci Total Environ 429:123-155

Vieno N (2007) Occurrence of pharmaceuticals in Finnish sewage treatment plants, surface waters and their elimination in drinking water treatment processes ( $\mathrm{PhD}$ thesis). Tampere University of Technology; No. 666.

Vieno N, Sillanpää M (2014) Fate of Diclofenac in municipal wastewater treatment plant - a review. Environ Int 69:28-39

Vieno N, Tuhkanen T, Kronberg L (2006) Removal of pharmaceuticals from drinking water treatment. Effect of chemical coagulation. Environ Technol 27:183-192

Viganò L, Benfenati E, van Cauwenberge A, Eidem JK, Erratico C, Goksøyr A, Kloas W, Maggioni S, Mandich A, Urbatzka R (2008) Estrogenicity profile and estrogenic compounds determined in river sediments by chemical analysis, ELISA and yeast assays. Chemosphere 73:1078-1089

Vogna D, Marotta R, Andreozzi R, Napolitano A, d'Ischia M (2004) Advanced oxidation of the pharmaceutical drug diclofenac with $\mathrm{UV} / \mathrm{H}_{2} \mathrm{O}_{2}$ and ozone. Water Res 38:414-422

Von Gunten U (2003) Ozonation of drinking water: Part I. Oxidation kinetics and product formation. Water Res 37:1443-1467

Von Sonntag C (2008) Advanced oxidation processes. Mechanistic aspects. Water Sci Technol 58:1015-1021

Vulliet E, Cren-Olive C, Grenier-Loustalot M (2011) Occurrence of pharmaceuticals and hormones in drinking water treated from surface waters. Environ Chem Lett 9:103-114
Weber S, Gallenkemper M, Melin T, Dott W, Hollender J (2004) Efficiency of nanofiltration for the elimination of steroids from water. Water Sci Technol 50:9-14

Wert EC, Gonzales S, Dong MM, Rosario-Ortiz FL (2011) Evaluation of enhanced coagulation pretreatment to improve ozone oxidation efficiency in wastewater. Water Res 45:5191-5199

Wright-Walters M, Volz C (2007) Municipal wastewater concentrations of pharmaceutical and xeno-estrogens: wildlife and human health implications. Proceedings of the 3rd National Conference on Science \&Technology, Greensboro

Xu P, Drewes JE, Kim T, Bellona C, Amy G (2006) Effect of membrane fouling on transport of emerging organic contaminants in NF/RO membrane applications. J Membr Sci 279:165-175

Yang X, Flowers RC, Weinberg HS, Singer PC (2011) Occurrence and removal of pharmaceuticals and personal care products (PPCPs) in an advanced wastewater reclamation plant. Water Res 45:52185228

Yoon Y, Westerhoff P, Snyder SA, Wert EC, Yoon J (2007) Removal of endocrine disrupting compounds and pharmaceuticals by nanofiltration and ultrafiltration membranes. Desalination 202:1623

Zhang Y, Zhou JL (2005) Removal of estrone and 17 $\beta$-estradiol from water by adsorption. Water Res 39:3991-4003

Zhang Y, Zhou JL, Ning B (2007) Photodegradation of estrone and $17 \beta$ estradiol in water. Water Res 41:19-26

Zhou H, Liu J, Xia H, Zhang Q, Ying T, Hu T (2015) Removal and reduction of selected organic micro-pollutants in effluent sewage by the ozone-based oxidation processes. Chem Eng J 269:245-254

Zorita S, Mårtensson L, Mathiasson L (2009) Occurrence and removal of pharmaceuticals in a municipal sewage treatment system in the south of Sweden. Sci Total Environ 407:2760-2770

Zuccato E, Castiglioni S, Fanelli R, Reitano G, Bagnati R, Chiabrando C, Pomati F, Rossetti C, Calamari D (2006) Pharmaceuticals in the environment in Italy: causes, occurrence effects and control. Environ Sci Pollut Res 13:15-21

Zwiener C, Frimmel FH (2003) Short-term tests with a pilot sewage plant and biofilm reactors for the biological degradation of the pharmaceutical compounds clofibric acid, ibuprofen, and diclofenac. Sci Total Environ 309:201-211 